NOTES

\title{
AN FDIC PRIORITY OF CLAIMS OVER DEPOSITORY INSTITUTION SHAREHOLDERS
}

\author{
SAMANTHA EVANS*
}

\section{INTRODUCTION}

Over the past decade, failures of federally insured depository institutions have increased to a crisis point. ${ }^{1}$ Einbezzlement, excessive coinpensation, improper lending practices, and other types of insider abuse and fraud by directors, officers, and various third parties have been present in a staggering number of these failures. ${ }^{2}$ The Federal Deposit Insurance Corporation (FDIC) has been active in litigating civil claims against such directors and officers to recoup the billions of dollars in government funds lost in reimbursing depositors and other creditors of the failed institutions. $^{3}$ To this end, the FDIC has urged that it should lave priority

* The author thanks Ira Paul and Lawrence Baxter for their assistance.

1. The failure of 79 banks in 1984 established a post-Depression record, only to be exceeded by 120 in 1985, 138 in 1986, 184 in 1987, 200 in 1988, and 206 in 1989-the highest number since the creatiou of the Federal Deposit Insurance Corporation (FDIC). FEDERAL DePosrt INSURANCE CORPORATION, 1989 ANNUAL REPORT 101 (1990) [hereinafter 1989 FDIC REPORT] (Table 122). Iu 1990, 168 banks failed. FDIC Reports Decline in Bank Failures; Pays Off Insured Deposits at Mass. Bank, 56 Banking Rep. (BNA) 13 (Jan. 7, 1991).

2. Estimates of the amount of fraud in the banking industry vary. The Office of the Comptroller of the Currency (OCC), the Department of Justice, the Governmeut Accounting Office (GAO), and the FDIC each conduct regular studies of the causes of bank failures. The OCC's study cited insider abuse as a significant factor in $35 \%$, and material fraud in $11 \%$, of the bank failures studied. See OfFice of the Comptroller of the CurRency, Bank Failure: AN Evaluation of the Factors Contributing to the Fallure of NATIONAL BANKS 9 (1988). The FDIC reported in its latest annual report that about oue-quarter of all banks that failed in 1989 experieuced soine form of insider abuse or criminal fraud. See 1989 FDIC REPORT, supra note 1, at 16. For a discussiou of the studies conducted by the GAO and the Resolution Trust Corporation (RTC), see infra notes 3941 and accompanying text. For a description of the major frauds and insider abuses in financial institutions, see Fraud in America's Insured Depository Institutions: Hearings Before the Senate Comm. on Banking, Housing, and Urban Affairs, 101st Cong., 2d Sess. 60, 61-64 (1990) [hereinafter Bank Fraud Hearings] (statement of Benton E. Gup, Chair of Banking, University of Alabama).

3. Whenever a financial institution fails, the FDIC conducts an investigation of officers, directors, and attorneys, and evaluates the ueed for legal action. As of April 1990, the FDIC had approxinately 1300 opeu investigations and 350 suits pending. Officers and Directors Are Targets for FDIC Suits, FDIC Associate Counsel Warns, 54 Banking Rep. (BNA) 690 (Apr. 26, 1990). 
over all other claimants in collecting damages agamst directors and officers, regardless of whether other claimants received judgments before the FDIC. ${ }^{4}$ This Note argues that neither federal common law nor statute authorizes such a priority.

The FDIC's role as insurer of failed national and state depository institutions permeates the day-to-day operation of these institutions even before a state or federal regulator declares thein insolvent. The FDIC regulates these institutions through its powers to examine records, to require various financial and accounting reports of institutions, and to proinulgate rules and regulations that inamtain stability in the banking industry. ${ }^{5}$ The FDIC also possesses the power to becoine the receiver of any insured institutions that fail. ${ }^{6}$ In accordance with its congressional Inandate, the FDIC inanages each failed or failing federally insured institution (whether chartered by a state or the federal government) in preparation for either hquidation or sale to a solvent institution. ${ }^{7}$ The FDIC also investigates the cause of each institution's failure.

The issue of an FDIC priority over shareholders arises when the FDIC's investigation of a depository institution's failure indicates that misinanageinent or fraud affected the stability of the institution and there are pending shareholder suits agaimst the perpetrators of that mismanageinent or fraud. The FDIC has an interest both as an insurer and as a representative of depositors in controlling the level of safety and soundness in each insured institution's banking practices. If a failed institution has experienced mismanageinent or fraud, the FDIC, on behalf of either itself as insurer or the institution's depositors, inay initiate a suit against the alleged wrongdoers to recover damages. ${ }^{8}$ Defendants in this suit inay also have a fiduciary duty to protect the equity interests of institution shareholders; inismanageinent or fraud on the part of an institution's officers or directors constitutes a breach of this duty. Thus, shareholders of the failed institution inay pursue the same defendants in private individual or class actions. ${ }^{9}$ In many cases, a single judgment for mismanagement of a financial institution is sufficient to deplete entirely the

4. See Bank Fraud Hearings, supra note 2, at 134, 144-45 (1990) (FDIC and RTC Comments on S. 1970).

5. See Federal Depostr Insurance Corporation, Federal Deposit Insurance CorPORATION: THE FIRST FIFTY YeARS 116-27 (1984) [hereinafter THE FIRST FIFTY YeARS] (available from the FDIC).

6. See id. at 83-87.

7. In a limited number of situations in which an institution is insolvent and is a vital part of a coinmunity, the FDIC will "bail out" the institution to preserve banking in that community. See infra note 36 and accompanying text.

8. See 12 U.S.C.A. § 1821(d), (g) (West 1989 \& Supp. 1991).

9. See, eg., Howard v. Haddad, 916 F.2d 167 (4th Cir. 1990). But see Popkin v. Jacoby (In re Sunrise Sec. Litig.), 916 F.2d 874 (3d Cir. 1990) (claims against former officers and directors of a 
wrongdoing official's assets or hability insurance fund. In such cases, a conflict arises at the time of judgment collection between the FDIC, which seeks assets to pay off depositors or to replenish its insurance fund, and the shareholders, who seek compensation for their investment loss. Both parties look to the same assets for compensation.

One circuit court has created a federal common law rule of priority for the FDIC over depository institution shareholders in collecting judgments against defendants whose assets are insufficient to satisfy both the FDIC and shareholders. ${ }^{10}$ Upon the FDIC's initiation of suit agamst officers and directors of a failed financial institution, this rule of priority directs a court to stay collection of all damages awarded shareholders until the completion of the FDIC's case and its collection of any awarded damages. ${ }^{11}$

Whether the FDIC should have such a priority is an important yet unresolved question that carries significant implications for shareholders' rights. At present, three federal circuits have addressed the issue of FDIC priority over shareholders in fraud, mismanagement, and other claims agamst bank officers and directors. ${ }^{12}$ These three decisions have adopted conflicting positions on the need for a general common law rule of FDIC priority. In Gaff v. FDIC,13 the Court of Appeals for the Sixth Circuit held that the FDIC has priority over stockholders in claims against a bank's former officers and directors. ${ }^{14}$ By contrast, the Court of Appeals for the Eleventh Circuit in FDIC v. Jenkins ${ }^{15}$ reached the opposite result and demed the FDIC priority. ${ }^{16}$ The Court of Appeals for the Fourth Circuit exphicitly followed Jenkins in Howard v. Haddad,$^{17}$ and denied the FDIC priority over damage awards. ${ }^{18}$

Despite the inconsistent holdings of Gaff and Jenkins, both the Sixth Circuit and the Eleventh Circuit based their analyses on the

failed savings and loan association were derivative in nature and therefore could not be brought directly as a class action).

10. See Gaff v. FDIC, 919 F.2d 384 (6th Cir. 1990), modified on reh'g, 933 F.2d 400 (6th Cir. 1991).

11. See id. at 397; see also FDIC v. American Bank Trust Shares, Inc., 412 F. Supp. 302 (D.S.C. 1976) (staying a shareholder suit against bank officers and directors pending outcome of FDIC litigation against same defendants), vacated, 558 F.2d 711 (4th Cir. 1977).

12. See Gaff v. FDIC, 919 F.2d 384 (6th Cir. 1990); Howard v. Haddad, 916 F.2d 167 (4th Cir. 1990); FDIC v. Jenkins, 888 F.2d 1537 (11th Cir. 1989).

13. 919 F.2d 384 (6th Cir. 1990).

14. See id. at 396.

15. 888 F.2d 1537 (11th Cir. 1989).

16. See id. at $\mathbf{1 5 4 6 .}$

17. 916 F.2d 167 (4th Cir. 1990). Because the Fourth Circuit explicitly adopted the holding in Jenkins, and did not contribute any additional analysis on the issue of an FDIC priority, this Note will not address Haddad in any detail.

18. See id. at 170 . 
Supreme Court's decision in United States v. Kimbell Foods, Inc., 19 which set forth the appropriate test for determining whether a federal program requires a priority over private interests to achieve Congress's goals in creating the program. In Kimbell Foods, the Court apphed a two-part analysis to deny the Small Business Administration (SBA) and Farmers Home Administration (FHA) a federal common law priority over competimg lienholders im collectimg payment on government loans. ${ }^{20}$ The Court found that state law, as opposed to a uniform federal law, governed the priority of liens created by the SBA and FHA loans. ${ }^{21}$ The Court held that federal courts may create a uniform rule of priority for a federal program only if (1) federal law apphies to the program, and (2) a uniform law is necessary to achieve the federal program's goals. ${ }^{22}$ To determine the second part of this analysis, the Court created a threefactor test that balances the extent to which uniformity is necessary to achieve the program's goals, the effect state laws would have on the program, and the impact a uniform rule would have on state commercial practices. $^{23}$

This Note analyzes the need for a uniform rule of FDIC priority over shareholders in bank-related hitigation in light of the analysis set forth in Kimbell Foods. The Note concludes that a uniform rule of priority for the FDIC im judgment and settlement collections is not essential to the FDIC's achievement of stability in the banking industry, and therefore the FDIC shonld not receive absolute priority over claims of depository institution shareholders.

To place the current circuit conflict in context, Part I provides an overview of the existing climate of depository institution failures and FDIC management of this crisis. Part II describes the facts and reasoning of the two circuit cases that have addressed the issue of an FDIC priority, Jenkins and Gaff, and argues that neither case has apphed properly the Kimbell Foods balancing test. Part III analyzes a rule of priority for the FDIC in judgment collections against bank-related defendants in hight of the requirements for federal common law priority rules set out in Kimbell Foods, concluding that current federal common law jurisprudence does not mandate FDIC priority. Part IV explores the legislative history of the Financial Institutions Reform, Recovery and Enforcement Act of 1989 (FIRREA), an ommbus financial institution reform, for the
19. 440 U.S. 715 (1979).
20. See id. at 718.
21. See id. at 729.
22. See id. at 726-33.
23. See id. at 728-29. 
possibility of an implicit provision for FDIC priority over depository institution shareholders in judgment collection. This part concludes that there is no authority for an FDIC priority under the current statutory framework. Part V discusses the legislative history of an explicit FDIC priority of claims provision in various bills introduced in Congress since the oinnibus reform, including the current Senate reform bill. Part VI concludes that the achieveinent of an FDIC priority over shareholders through development of federal common law is not only unnecessary, but would be detrimental to the depository imstitution industry.

\section{The FDIC's Role IN THE DEPOSITORY INSTITUTION INDUSTRY}

Congress created the FDIC in the Banking Act of $1933^{24}$ in response to the failure of niore than 9000 commercial banks between 1930 and $1933^{25}$ and the bank rums caused by these failures. Congress envisioned the federal deposit insurance systein as a primary vehicle to promote stability in a depressed banking industry and to protect banks from the risk of "bank runs."26 Federal deposit insurance reassures depositors of the safety of deposited funds by guaranteeing payinent on all accounts containing $\$ 100,000$ or less, and thus decreases depositors' incentives to withdraw funds before a rumored bank closure.

By almost any measure, federal deposit insurance successfully stabilized the U.S. banking system after the crisis of the early 1930s. ${ }^{27}$ Yet

24. Banking Act of 1933, Pub. L. No. 73-66, $\S 8,48$ Stat. 162, 168-80 (amended 1935). The Banking Act of 1933 introduced a temporary plan of federal deposit insurance. This legislation was followed two years later by the comprehensive Banking Act of 1935, which permanently established the FDIC and granted it supervisory authority over all insured banks that were not supervised by a federal agency. See Banking Act of 1935, Pub. L. No. 74-305, § 101, 49 Stat. 684, 684-703. In 1950, this section was withdrawn from the Federal Reserve Act and made a separate act. See Federal Deposit Insurance Act, Pub. L. No. 81-797, § 1, 64 Stat. 873, 873 (1950) (codified as amended at 12 U.S.C. $\S 1811$ (Supp. I 1989)). A federal district court summarized the national economic environinent surrounding the creation of the FDIC:

The FDIC is a corporation originally established during the economic and banking crisis of the early 1930s when thousands of banks were forced to close their doors. It was created to restore and reinforce public confidence in the banking system, to promote safe and sound banking practices and the stability of banks, to obviate runs on banks by depositors, to safeguard deposits through deposit insurance, and to prevent the recurrence of the events of 1931 and 1932 which sapped banking strength and climaxed in the "bank holiday" of March, 1933.

FDIC v. Allen, 584 F. Supp. 386, 397 (E.D. Tenn. 1984) (citations omitted).

25. Kerry COOPER \& Donald R. Fraser, Banking Deregulation aNd the New CoMPETtTION IN Financial Services 150-51 (1984).

26. See THE FIRST FIFTY YeARS, supra note 5, at 4. A bank run occurs most often when negative reports about a bank's solvency imduce depositors to withdraw their funds froin the allegedly ailing institution. For a description of a typical bank run, see GEORGE J. BENSTON ET AL., Perspectives on Safe \& SOUNd Banking 65-66 (1986).

27. See COOPER \& FRASER, supra note 25 , at 161 ("An average of only 48 banks per year failed in the first five years after establishment of the FDIC (1934-1939)."). 
after half a century of relative calm, the sudden emergence of a savings and loan crisis and the bailouts of a number of large banks now present the FDIC with the possibility of a significant drain on its insurance funds. ${ }^{28}$ To best preserve its insurance funds, the FDIC must manage mdividual bank failures quickly and effectively and recapitalize its funds with all available assets, including proceeds from litigation. Speed is a crucial factor im maintaining stability im the face of an institution's economic failure; if the FDIC can successfully assume the operation of a failing institution, or quickly transfer operation to a solvent bank, then depositors will not experience an interruption of service, which is a significant cause of loss of consumer confidence and bank runs.

\section{A. FDIC Management of a Bank Failure}

When an insured depository institution fails, the FDIC will generally be appointed as its receiver. ${ }^{29}$ Whetlier a failing institution is federally or state cliartered determines the metliod by which the FDIC becomes the receiver. Federal banks inay have the FDIC appointed as a receiver if one of eiglit enumerated conditions exists. ${ }^{30} \mathrm{~A}$ state bank, on the otlier hand, may be seized by eitlier of two inethods. Under the first

28. The Bank Insurance Fund, which insures all approved national and state banks, was established by 12 U.S.C.A. $\S 1821$ (a)(5) (West 1989); the Savings Association Insurance Fund, which insures qualifying savings and loan associations, was established by 12 U.S.C.A. $\S 1821$ (a)(6) (West 1989). The FDIC manages both funds. Before 1989, the Federal Savings and Loan Insurance Corporation (FSLIC) insured deposits in savings and loan institutions. On August 8, 1989, all FSLIC assets were transferred to the FSLIC Resolution Fund pursuant to 12 U.S.C.A. $\S 1821$ a (a)(2) (West 1989).

In addition to reimbursements that the FDIC procures from litigation after assisting a bank, the funds derive their revenues from regulatory depository institution assessinents (based on a percentage of total assets) and interest earned on investment of the assessments in U.S. Treasury obligations. See FIRREA, Pub. L. No. 101-73, § 208, 103 Stat. 183, 206-16 (codified as amended at 12 U.S.C.A. $\S 1817$ (West Supp. 1991)).

29. See THE FIRST FIFTY YeARS, supra note 5, at 83.

30. See 12 U.S.C.A. $\$ 203(a)$ (West Supp. 1991). The Coinptroller of the Currency may appoint the FDIC as conservator of a bank whenever the Comptroller determines that one or inore of the following circumstances exist:

(1) any one or inore of the conditions for appointunent of a receiver for the bank specified in section 191 of [the Bank Conservation Act] are present;

(2) the bank is not likely to be able to meet the demands of its depositors or pay its obligations in the normal course of business;

(3) the bank is in an unsafe or unsound condition to transact business, including having substantially insufficient capital or otherwise;

(4)(A) the bank has incurred or is likely to incur losses that will delete all or substantially all of its capital, and

(B) there is no reasonable prospect for the bank's capital to be replenished without Federal assistance;

(5) there is a violation or violations of laws, rules, or regulations, or any unsafe or unsound practice or condition which is likely to cause insolvency or substantial dissipation of assets or earnings, or is likely to weaken the bank's condition or otherwise seriously prejudice the interests of its depositors; 
method, the FDIC may accept an appointment as receiver of an msured state institution after the institution has been seized by a state banking agency. ${ }^{31}$ Under the second method, the FDIC may appoint itself as receiver of an insured state institution if the state has already put the institution into receivership. ${ }^{32}$

Once the FDIC has become receiver or conservator of a depository institution, it may protect depositors in three ways. ${ }^{33}$ First, the FDIC may close and liquidate an institution and pay depositors out of the deposit insurance fund the full value of their insured deposits (up to $\$ 100,000$ per account). ${ }^{34}$ Second, the FDIC may assist in the absorption of the failed institution by anotler institution in a "purcliase and assumption" transaction. ${ }^{35}$ Third, when the continued existence of a failing depository institution is essential to its community, the FDIC may

(6) there is concealment of books, papers, records, or assets of the bank, or refusal to submit books, papers, records, or affairs of the bank for inspection to any examiner or to any lawful agent of the Comptroller;

(7) there is a willful or continuing violation of an order enforceable against the bank under section 1818(i) of this title; or

(8) the bank's board of directors consists of fewer than 5 members.

Id.

31. See 12 U.S.C.A. \$1821 (c)(1), (c)(3) (1989); see, e.g., FDIC v. Jenkins, 888 F.2d 1537, 1538-39 (11th Cir. 1989) (reporting that the Florida Department of Banking and Finance declared the federally insured, state chartered Park Bank insolvent and appointed the FDIC as receiver of the bank).

32. See 12 U.S.C.A. $\$ 1821(c)(1)$, (c)(4) (1989).

33. See COOPER \& FraSER, supra note 25 , at 157.

34. The limit of the FDIC's liability per depositor was increased to $\$ 100,000$ by the Depository Institutions Deregulation and Monetary Control Act of 1980, Pub. L. No. 96-221, § 308(a)(1)(C), 94 Stat. 132, 147 (codified as amended at 12 U.S.C. $\S 1821$ (a)(1) (1988)).

35. See 12 U.S.C. $\S 1823$ (c)(2), (c)(4)(A) (1988). In a purchase and assumption transaction, the FDIC attempts to:

arrange for another bank to "purchase" the failed bank and reopen it without interrupting banking operations and with no loss to the depositors. A purchase and assumption involves threc entities: the receiver of the failed bank, the purchasing bank, and the FDIC as insurer. In most cases, the FDIC is appointed receiver by the appropriate banking authority and thus acts in two separate capacities: as receiver and as corporate insnrer.

As soon as the receiver is appointed, the FDIC solicits bids from other banks for the purchase of the failed bank and assumption of its liabilities. ... After receiving the bids, the FDIC Board of Directors determines whether the purchase and assumption is feasible according to the statutory requirements of 12 U.S.C. $\$ 1823(\mathrm{e})$.

Gunter v. Hutcheson, 674 F.2d 862, 865 (11th Cir.) (citation and footnote omitted), cert. denied, 459 U.S. 826 (1982).

Often it is not possible for the FDIC immediatcly to arrange for a receiver of the failed institution. In such a ease, the FDIC may use its authority to establisli a "bridge bank" to take over and reorganize tcmporarily the operations of a failed institution to prepare it for a purchase and assunption transaction. Under 12 U.S.C.A. \$ 1821(n) (West 1989), the FDIC may establish a bridge bank when an insured bank is closed and more time is needed to find a permanent solution. Although not subject to any reserve requirements, a bridge bank is a full-service national bank established on an interim basis to assume the deposits, certain liabilities, and substantially all of the assets of a failed bank. The bridge bank may be operated for up to five years by a board of directors appointed by the FDIC. Id. $\S 1821(\mathrm{n})(9)$. A bridge bank may be estabhished only if the cost of operating it does not 
provide resources to keep the institution afloat, ${ }^{36}$ take over the operation of the institution, and then reorganize it. This is called the "direct payout" method. The FDIC generally favors the purchase and assumption method over the hquidation and direct payout methods. ${ }^{37}$

\section{B. Litigation Against Bank Officers and Directors}

The FDIC's role as insurer and representative of depositors requires it to decide whether to bring actions against bank officers or inanagers for fraud or mismanagement of an institution. Corporate misinanagement and fraud contribute to a great number of depository institution failures. ${ }^{38}$ In a 1989 study of savings and loan failures, the General Accounting Office (GAO) discovered insider abuse and fraud at every one of the twenty-six failed thrifts studied. ${ }^{39}$ A 1991 study conducted by the

exceed the cost of liquidating the closed bank. The FDIC used bridge banks in the three largest bank failures in 1989. 1989 FDIC REPORT, supra note 1, at 12.

For more complete descriptions of the FDIC's options in structuring a depository institution failure, including the purchase and assumption transaction, see John F. Borenzi \& Arthur J. Murton, Resolution Costs of Bank Failures, 1 FDIC Banking REv. 1, 1-4 (1988); Michael B. Burgee, Purchase and Assumption Transactions Under the Federal Deposit Insurance Act, 14 ForUM $1146,1154-59$ (1979).

From a public policy perspective, the purchase and assumption solution is superior to a liquidation because if a bank is liquidated the community loses the services of the bank, the public loses confidence in the system, and customers with deposits that exceed the insured amount lose their uninsured funds. See Gunter, 674 F.2d at 865-66.

Sone theorists argue, however, that providing de facto $100 \%$ coverage via purchase and assumption transactions only promotes poor manageinent by banks and poor choice of banks by customers. Thus, they contend, purchase and assumption transactions have been part of the cause of the recent rash of bank failures rather than an appropriate response. See, eg., Daniel R. Fischel et al, The Regulation of Banks and Bank Holding Companies, 73 VA. L. REv. 301, 313-16 (1987) (arguing that FDIC use of purchase and assumption transactions and bail outs with de facto $100 \%$ insurance creates inoral hazard that banks will fail to internalize the cost of risky activities).

36. See 12 U.S.C. $\$ 1823$ (c)(1) (1988). But see id. § 1823(c)(4) ("No assistance shall be provided under this subsection in an amount in excess of that amount which the Corporation determines to be reasonably necessary to save the cost of liquidating.").

37. Froin 1987 to mid-1991, the FDIC arranged some forn of purchase and assumption transaction in $91 \%$ of its 863 bank interventions. By contrast, it provided direct assistance in five percent of the cases and hiquidated the failed bank in four percent of the eases. See Federal Deposit INSURANCE CORPoration, BANK INSURANCE FUND Mid-YeAr RESUlTS 8 (1990).

38. See supra note 2; see also 1989 FDIC REPORT, supra note 1, at 39 ("Various courts across the country during 1989 awarded more that $\$ 60$ million in restitution payments to the FDIC and the FSLIC from former officers, directors or borrowers at closed banks and thrifts who were convicted of embezzlement or other forms of bank fraud.").

39. See Untred States General Accounting Office, Thrift FaIlures: Costly FailURES Resulted from Regulatory Violations and UNSAFe Practices 2, 3, 23 (1989). The GAO review of savings and loan associations covered 26 institutions that the FSLIC either merged, hquidated, or began assisting between January 1, 1985 and September 30, 1987, or anticipated assisting as of September 30, 1987. These institutions represented over 50\% of FSLIC's estimated losses at the time. Id. at 2. 
Resolution Trust Corporation (RTC) found that suspected criminal conduct was present in fifty-eight percent of the 622 thrift institutions it held. ${ }^{40}$ The RTC investigation also discovered that potential insider criminal conduct contributed to insolvency in thirty-eight percent of the RTC thrifts. ${ }^{41}$

The FDIC possesses no authority to prosecute individuals on criminal charges; it inust instead refer suspected criminal conduct in financial institutions to the U.S. Department of Justice.42 The FDIC nay, however, file civil suits in its capacity as both receiver in a hquidation and corporate insurer in a purchase and assumption transaction. FDIC suits against individuals often assert claims of common law fraud, neghigence, breach of fiduciary duty, as well as violations of banking statutes and civil claims under RICO.43

The FDIC as receiver has a duty to investigate and to pursue all viable causes of action. Section 11(d) of the Federal Deposit Insurance Act (FDIA) ${ }^{44}$ sets forth the FDIC's duty as receiver to collect the assets of a bank and to enforce the full accountability of its officers and directors. The receiver inay institute any suit (on behalf of the bank), including shareholder derivative suits, that the bank itself could have commenced. ${ }^{45}$ In a depository institution hquidation, the Professional Liabilities Section of the FDIC's Litigation Branch helps the FDIC's Division of Liquidation investigate each institution failure to determine whether the FDIC as receiver should bring civil claims for monetary

40. See Resolution Trust Corporation, Semi-Annual Report of Investigations: Progress to DATE 12 (1991). As of June 30, 1991, the RTC was managing 212 thrifts and had resolved 410 . Id. at 5 .

41. Id. at 12 .

42. For a general discussion of the criminal laws that the Justice Department uses to prosecute financial institution officers and directors, see Renae V. Stevens, Note, Insider Abuse and Criminal Misconduct in Financial Institutions: $A$ Crisis?, 64 NOTRE DAME L. REV. 222, 234-41 (1989). Although the FDIC lacks authority to bring criminal actions, it has a criminal investigations unit (the "fraud squad") that investigates criminal activity in many open institutions and all closed banks. The RTC Office of Investigations conducts similar inquiries in all closed thrifts. Bank Fraud Hearings, supra note 2, at 114-17 (testimony of L. William Seidman, Chairman, FDIC).

43. Racketecr Influenced and Corrupt Organizations Act (RICO), 18 U.S.C. $\$ \S 1961-1968$ (1988); see Thomas P. Vartanian \& Michael D. Schley, Bank Officer and Director Liability-Regulatory Actions, 39 Bus. LAw 1021, 1023-28 (1984). In addition, the Financial Institution Reform, Recovery and Enforcement Act of 1989, Pub. L. No. 101-73, §§ 901-920, 951, 103 Stat. 183, 446-88, 498-99 (codified as amended in scattered sections of 12 U.S.C.A.), significantly increased civil monetary penalties and enhanced the enforcement powers of the FDIC-thns heightening thc potential for lawsuits against officers and directors.

44. 12 U.S.C.A. $\$ 1821$ (d) (West Supp. 1991).

45. See 12 U.S.C.A. \& 1821(d)(2)(A) (West 1989); see also Landy v. FDIC, 486 F.2d 139 (3d Cir. 1973) (holding that when a corporation is in receivership, shareholders' demand to bring suit on their behalf inust be inade on the receiver instead of the directors, and demand will be excused only if the FDIC was personally involved or interested in the alleged wrongdoing). 
damages against certain individuals. The Professional Liability Section then supervises the litigation of any claims made. ${ }^{46}$ In a purchase and assumption transaction, the FDIC in its capacity as a corporate insurer acquires the cause of action from the FDIC as receiver. ${ }^{47}$

\section{The Circuit Split}

The Supreme Court has not yet addressed the question of whether the FDIC sliould have a priority over depository institution shareholders in litigating or collecting awards against an institution's officers and directors. Only three circuits have addressed this issue. ${ }^{48}$ Under current

46. In 1989, the FDIC's professional liability litigation workload tripled to manage the cases and investigations arising out of 1250 failed depository institutions. 1989 FDIC REPORT, supra note 1 , at 39 . The litigation section recovered $\$ 100$ million from failed banks and thrifts during the year, a $56 \%$ increase over $\$ 64$ million in 1988 . Id.

47. The FDIC's status as the regulator and insurer of failed institutions permits it to bring civil suits against officers and directors: "As insurers of financial institutions, the FDIC and FSLIC regularly becoine assiguees or subrogees of claims of failed institutions in connection with payinent of assistance to a third-party acquirer of the institution." Vartanian \& Schley, supra note 43, at 1028; see also FDIC v. Ashley, 585 F.2d 157 (6th Cir. 1978) (holding that FDIC's status as a purcliaser of assets does not change inerely because it also acts as seller).

48. See Gaff v. FDIC, 919 F.2d 384 (6th Cir. 1990); Howard v. Haddad, 916 F.2d 167 (4th Cir. 1990); FDIC v. Jenkins, 888 F.2d 1537 (11th Cir. 1989). In addition, the Third Circuit las expressed in dictum what could be considered disapproval of an FDIC priority in Popkin v. Jacoby ( $I n$ re Sunrise Sec. Litig.), 916 F.2d 874 (3d Cir. 1990). In that case, depositors' suits against the bank in receivership confiicted with the FDIC's pursuit against the bank on similar claims in a shareholder derivative action. Although the Third Circuit granted the FDIC priority, it distinguished the facts froin the Eleventh Circuit case, Jenkins, and claimed that its holding was consistent with Jenkins. Id. at 889. The court hinted that, in a nonderivative case more factually analogous to Jenkins, it would deny the FDIC a priority: "To the extent that depositors assert individual, nonderivative fraud claims against the officers, directors, auditors, or attorneys of insolvent financial institutions, they may proceed on equal footing with FDIC against these defendants." Id.

Solne district courts have also addressed the issue. See In re Atlantic Fin. Sec. Litig., No. 890645, 1991 U.S. Dist. LEXIS 7439 (E.D. Pa. May 28, 1991) (denying the RTC's motion to stay shareliolder proceedings against bank officers and directors pending resolution of the RTC's claims against the same defendants); see also Crocker v. McMullan, 623 F. Supp. 963 (D. Miss. 1985) (court denied FDIC notion to stay sliareholder RICO srit against niajority shareholders because the shareliolders' action was not derivative), rev'd on other grounds sub. nom., Crocker v. FDIC, 826 F.2d 347 (5th Cir. 1987), cert denied, 485 U.S. 905 (1988). But see FDIC v. American Bank Trust Slares, Inc., 412 F. Supp. 302 (D.S.C. 1976), vacated and remanded, 558 F.2d 711 (4th Cir. 1977), in which the district court stayed a shareholder suit for fraud and deceit pending the outcome of FDIC litigation against bank officers and directors but declined to rule on an FDIC right to priority:

The court is presently also of the view that FDIC is entitled to a priority over subordinated capital noteliolders witlı respect to any recovery from directors and officers, and any policy insuring said persons. As a general rule, equity prefers the claims of innocent general creditors over the claims of sliareliolders or subordinated creditors deceived by officers of the corporation. However, before making a final determination on this point, the court at a proper tinie will give all parties an opportunity to be heard on the issue of priority of the disbursentent of funds recovered by any party.

Id. at 307-08 (citation ountted) (emplasis added). On renand, the district court did not inake any furtlier findings concerning an FDIC priority over slareholders on the recovery froin officers and 
law, the Sixth Circuit has accorded the FDIC a priority, ${ }^{49}$ but the Fourth ${ }^{50}$ and Eleventh ${ }^{51}$ Circuits have explicitly rejected an FDIC priority. In the Fourth and Eleventh Circuits, state law on damages collection governs disputes between the FDIC and bank shareholders. Altliough states are free to adopt a rule of FDIC priority, no state has yet done so. Rather, most states have opted for the rule that when a defendant's assets cannot satisfy both the FDIC's and shareholders' claims, the FDIC will compete equally with shareholders to collect damages on a pro-rata or first-im-time, first-in-right basis. ${ }^{52}$

The basic issue dividing the circuits is whether federal courts should create a federal common law rule that would allow the FDIC to collect dainages or to negotiate settlement awards before depository institution shareholders have an opportunity to do so. Such a rule would apply even if the shareholders filed suit or began settleinent negotiation before the FDIC. Although United States v. Kimbell Foods, Inc. ${ }^{53}$ is not directly on point on this issue, it is the leading Supreme Court case concerning federal common law priorities for the administration of federal programs.

The issue in Kimbell Foods was whether the SBA and FHA have priority over otlier, even semor and statutory, henholders in the foreclosure of collateral. ${ }^{54}$ Kimbell Foods involved two separate actions consolidated by the Supreme Court. ${ }^{55}$ In one action, the SBA claimed that its lien securing a loan it guaranteed took priority over a private hen that arose out of a security interest that preceded the federal guarantee. ${ }^{56}$ The district court held that federal law controlled the controversy and created a federal common law rule that federal statutory liens take priority over state and private liens. ${ }^{57}$ Although agreeing that federal law governs the SBA loan program, the Fifth Circuit fashioned a rule that, instead of according the federal agency absolute priority, incorporated UCC priorities based on order of perfection. ${ }^{58}$

directors. See FDIC v. American Bank Trust Shares, Inc., 460 F. Supp. 549 (D.S.C. 1978), aff'd, 629 F.2d 951 (4th Cir. 1980).

49. See Gaff, 919 F.2d at 396.

50. See Howard, 916 F.2d at 170 .

51. See Jenkins, 888 F.2d at 1546.

52. See infra text accompanying notes 140-45.

53. 440 U.S. 715 (1979).

54. See id. at 718.

55. Kimbell Foods, Inc. v. Republic Nat'l Bank, 557 F.2d 491 (5tl Cir. 1977) (the SBA case); United States v. Crittenden, 563 F.2d 678 (5th Cir. 1977) (the FHA case).

56. See Kimbell Foods, Inc. v. Republic Nat'1 Bank, 401 F. Supp. 316, 319 (N.D. Tex. 1975).

57. See id. at 321-22. The court determined that the federal rule fixing priority between federal liens and state created liens is that a non-federal lien only takes priority if it is "both earlier in time and clroate at the time the federal lien arises." Id. The court defined choate hens as only those liens reduced to judgment, regardless of perfection under state law. See id. at 322.

58. See Kimbell Foods, Inc. v. Republic Nat'l Bank, 557 F.2d 491, 503 (5th Cir. 1977). 
In the second case consolidated into Kimbell Foods, the FHA claimed that its federal contractual security interest in a tractor was superior to a subsequent repairman's hen. ${ }^{59}$ The district court granted summary judgment for the repairman's henholder and held that the repairman's hen was superior to the FHA's because both federal and state law accord priority to such liens. ${ }^{60}$ The Fifth Circuit affirmed in part and reversed in part, and held that federal common law governs the rights and habilities of parties in suits arising from FHA loan transactions, but that the UCC must guide the federal common law. ${ }^{61}$

The Supreme Court consolidated these cases and granted certiorari to determine whether, in the absence of a federal statute setting priorities, contractual hens arising from the SBA and FHA loan programs take automatic priority over other liens. The Court ruled that they do not.62 The Court's analysis consisted of two steps. First, the Court noted that federal law applies to federal loan programs. ${ }^{63}$ Second, the Court conducted a three-factor test, which considered the necessity of a uniform rule, the impact state law would otherwise liave on the programs, and the extent to which a uniform rule would frustrate state commercial practices. ${ }^{64}$ The Court concluded that the SBA and FHA loan programs did not require a uniform federal common law rule of priority and declined to override state law on hen priorities. ${ }^{65}$

The Eleventll Circuit in FDIC v. Jenkins ${ }^{66}$ and the Sixtl Circuit in Gaff v. $F D I C^{67}$ addressed an issue closely related to that addressed in Kimbell Foods: whether the FDIC should have a priority over bank shareholders in suits agamst bank officers and directors. Both Jenkins and Gaff held that a federal common law rule of priority for the FDIC, as for any federal agency, must satisfy the Kimbell Foods criteria. Although the two courts reached opposite conclusions, neither the Eleventh nor the Sixth Circuits adequately explored this question under the Kimbell Foods analysis.
59. See Crittenden, 563 F.2d at 679.
60. See id.
61. See id. at $680-81$.
62. Kimbell Foods, 440 U.S. at 718.
63. See id. at 726.
64. See id. at 728-29. For an in-depth discussion of the Kimbell Foods analysis, see infra Part III.

65. See Kimbell Foods, 440 U.S. at 733.

66. 888 F.2d 1537 (11th Cir. 1989).

67. 919 F.2d 384 (6th Cir. 1990); see also Howard v. Haddad, 916 F.2d 167, 170 (4th Cir. 1990) (explicitly adopting the Jenkins loolding). 
A. FDIC v. Jenkins

In FDIC v. Jenkins, ${ }^{68}$ the Eleventh Circuit deuied the FDIC a priority over bank shareholders when it attempted to collect the proceeds of any settlement or to levy on any judgment against the officers and directors of a Florida bank. In Jenkins, shareholders were concurrently suing many of the same defendants for securities fraud, common law fraud, civil conspiracy, negligence, and civil theft. ${ }^{69}$ The FDIC brought a separate action in a U.S. district court against the shareholders seeking a declaratory judgment that the FDIC's claims against the bank-related defendants should have priority over the shareholders' claims agamst the same defendants. ${ }^{70}$ The district court held that several pohicy considerations supported the FDIC's position and granted priority to the FDIC. ${ }^{71}$ On appeal, the Eleventh Circuit reversed on two grounds. First, the court refused to recognize an "implicit" FDIC priority in FIRREA. ${ }^{72}$ Second, the court applied the federal common law analysis set forth in Kimbell Foods to the issue of whether the FDIC should have priority. ${ }^{73}$ The court concluded that the nature of FDIC hitigation against bankrelated defendants does not require a uniform federal common law rule of priority. ${ }^{74}$

Notwithstanding the court's concession that the "preservation of the permanent insurance fund is vital to the continued health of the nation's banking systein," it held that the FDIC must nevertheless limit itself to measures "authorized in the Federal Deposit Insurance Act to maximize recovery to the fund."75 The liolding reflected Congress's specific rejection of an explicit claims priority provision during the drafting of its most recent banking legislation, FIRREA. ${ }^{76}$ This rejection indicated to the court a lack of statutory authority for the FDIC's contention that a priority is implicit in FIRREA because without such a provision "the

\footnotetext{
68. 888 F.2d 1537 (11th Cir. 1989).

69. Id. at 1538.

70. Id.

71. The court considered shareholders' knowledge of general risk when making investments and the inequity of making general creditors share equally with shareholders. The court fashioned an FDIC priority by enjoining the shareholders from collecting proceeds of any settlement with, or levying on any judgment against, the bank-related defendants and by ordering that any judgment obtained by shareholders state its subordination to judgments obtained by the FDIC. See id. at
} 1539.

72. Pub. L. No. 101-73, 103 Stat. 183 (codified as amended in scattered sections of 12 U.S.C.A.). See Jenkins, 888 F.2d at 1541, 1544. For a discussion of whether Congress implicitly intended the FDIC to have a priority in the FIRREA amendments to the FDIA, see infra Part IV.

73. See Jenkins, 888 F.2d at $1545-46$.

74. See id. at 1546.

75. Id. at 1541 .

76. An FDIC priority provision included in a Senate version of FIRREA, see S. 774, §214(o), 101st Cong., 1st Sess. (1990), is conspicuously absent from the enacted version. 
FDIC could not carry out its alleged statutory mission unless it had the ability to assert priority over the shareholders."77 The court reasoned that Congress rejected the provision so as not to deter private suits against officers and directors of failed institutions. ${ }^{78}$ Thus, the court refused to "fill the interstices of federal legislation"79 with "judicial expansion of the express powers and rights granted to the FDIC . . . by Congress." 80

The Eleventh Circuit's alternative holding discussed the Kimbell Foods prerequisites for the creation of a federal common law rule of priority. Although the court quoted the three factor test from Kimbell Foods that "a court inust consider," it declined to apply these considerations to the Jenkins facts. ${ }^{81}$ The Eleventh Circuit apparently believed that the Kimbell Foods analysis nust be applied only in the presence of a congressional goal: "Any [federal] rule fashioned must have its base on the goal of effectuating congressional pohicy." 82 Thus, because the court did not find such a goal in the area of an FDIC priority over shareholders on which to base the test: "We are not convinced that Congress considered collections against parties such as the bank-related defendants im this case as a necessary part of the recovery to the deposit insurance fund." 83 They concluded that "[a]ny such priority over third-party lawsuits will have to coine from Congress, not this Court." 84 The court erred in assuming that the Kimbell Foods analysis required some kind of threshold determination of a congressional goal and by, therefore, not applying the analysis to the facts in Jenkins.

The Jenkins court further denied the FDIC's alternative contention that it is entitled to a federal common law rule of priority based on an analogy with the general principles of equitable subordination in bankruptcy. ${ }^{85}$ As einbodied in federal bankruptcy law, the doctrine of equitable subordination gives general creditors, represented by the bankruptcy trustee, priority over shareholders in the distribution of the bank's assets. The Jenkins court held, however, that the doctrine is inapplicable to proceedings "against solvent third-parties in non-derivative shareholder

77. Jenkins, 888 F.2d at 1541 .

78. See id. at 1538 n.1, 1540 n.5. Congress has considered a priority provision for the FDIC in various recent banking bills. For a discussion of the congressional history of an FDIC priority provision, see infra Part V.

79. United States v. Kimbell Foods, Inc., 440 U.S. 715, 727 (1978).

80. Jenkins, 888 F.2d at 1541.

81. See id. at 1545 .

82. Id. at 1546.

83. Id.

84. Id.

85. See id. at 1545 . The Bankruptcy Code was not direetly applicable to the controversy in the case because it does not govern bank failures. See 11 U.S.C. § 109(b)(2) (1988). 
suits," 86 such as the Jenkins shareholders' private suit against bank officers and directors.

\section{B. Gaff v. FDIC}

In $G a f f v . F D I C,{ }^{87}$ the Sixth Circuit erroneously drew an analogy with the Kimbell Foods test to conclude, unlike Jenkins, that the FDIC should have a priority under federal common law over the competing claims of shareholders. ${ }^{88}$ In Gaff, the FDIC became the receiver for the National Bank of Traverse City, a small national bank in Michigan, which allegedly became imsolvent due to fraud and mismanagement. As part of a purchase and assumption agreement in which the FDIC sold the bank's assets and habilities to a healthy bank, the FDIC, as receiver, sold some assets to itself $\mathrm{i}$ its eorporate capacity. Those assets imcluded the bank's claims for fraud and mismanagement against the officers and directors of the bank. ${ }^{89}$

Purporting to apply the Kimbell Foods analysis to the question of whether the FDIC should have a priority in its collection of settlement proceeds over bank shareholders with similar claims against bank-related defendants, the Sixth Circuit created a federal common law rule to provide the FDIC with such a priority. ${ }^{90}$ Instead of applying the Kimbell Foods test, however, the court distimguished the case from the facts im Kimbell Foods, which demed hen priority to the SBA and FHA, by finding that the national bank insurance system differs in two respects from the loan prograins of the SBA and FHA.91 "First, the bank insurance system needs national uniformity by its nature [because u]nlike the SBA and the [FHA], the FDIC has not prepared itself for the application of state law to its transactions."92 Second, although the SBA and FHA have ample time to structure their transactions, "the FDIC must operate under severe timie constraints when it closes a bank." 93

86. Jenkins, 888 F.2d at 1545 . The court expressed some hesitation in this part of the holding because of the lack of consensns on the bankruptcy rights of shareholders in third-party actions:

[T] 1978 revision of the Bankruptcy Code (Amended 1984) arguably approves of the position that such shareholders may proceed in suits against third parties on an equal statns with general creditors. The express terms of section 510(b) of the 1978 Bankruptcy

Code apply only to claims against the debtor or an affiliate of a debtor.

Id. at 1545 (citation omitted).

87. 919 F.2d 384 (6th Cir. 1990).

88. See id. at $387,396$.

89. Id. at 386. The court pointed out that the FDIC had already settled its claims against the officers and directors with their liability insurer, contingent on the outcome of this case. According to counsel in the case, the settlement nearly depleted the available insurance fund. Id.

90. See id. at 387.

91. See id. at 388.

92. Id. at 388-89.

93. Id. at 389 . 
The Sixth Circuit found alternative support for an FDIC priority rule in the "policies behind" FIRREA. ${ }^{94}$ The court interpreted congressional policy by reference to three provisions in FIRREA: "First, section 212(a) vests in the FDIC 'all rights, titles, powers, and privileges of the insured depository institution, and of any stockholder . . . with respect to the institution and the assets of the institution .... This suit involves the overall 'assets of the institution." "95 Second, another subsection of FIRREA provides that "[n]otwithstanding any other provisions of Federal law, the law of any State, or the constitution of any State, the [FDIC], upon the payment [of insurance proceeds] . . . shall be subrogated to all rights of the depositor against such institution or branch to the extent of such payment or assumption."96 The court noted that this provision "demonstrate[s] Congress's intent to preenpt state law by occupying the field of national bank insurance and the FDIC's rights."97 Third, the Gaff court reasoned that FIRREA's cross guarantee provision-which requires solvent subsidiaries of a holding company to bear the costs of a related subsidiary's failure-reveals that "the liability of officers and directors of a bank are determined under federal law."98 According to the court, certain language in the legislative history of FIRREA indicates an exphicit congressional intent to nationalize the law of directors' and officers' hability:

Title II preempts State law with respect to claims brought by the FDIC in any capcity [sic] against officers or directors of an insured depository imstitution. The preemption allows the FDIC to pursue claims for gross negligence or any conduct that demonstrates a greater disregard of a duty of care. ${ }^{99}$

This alternative ground for an FDIC priority is quite problematic. The court does not find authority for the priority in the statute, but rather in a general notion of congressional imtent to create an arsenal of power for the FDIC. What is troubling is that the Kimbell Foods analysis itself incorporates a consideration of congressional policy in its threefold balancing test. It is not clear, however, what authority the court

94. See id. at 390-91. The court also noted that a priority would be consistent with the "national policies expressed in the Bankruptcy Code" and the principle of equitable subordination. See id. at 394.

95. Id. at 390 (quoting FIRREA, § 212(a), 12 U.S.C.A. § 1821(d)(2)(A)(i) (1989)) (omissions appear in the opinion). It is unclear why the court claims that the "assets of the institution" include a cause of actiou against officers and directors and yet loolds that this provision is not dispositive but merely indicative of congressioual policy.

96. Id. (quoting FIRREA, § 212(a), 12 U.S.C. § 1821(g) (1989)).

97. Id. at 391.

98. Id. Cross guarantees enable the FDIC to recover part of the costs of liquidating or aiding a failed institution from solvent institutions in the same lolding company. 1989 FDIC REPORT, supra note 1 , at 57.

99. H.R. Conf. Rep. No. 222, 101st Cong., 1st Sess. 398 (1989). 
uses to renew the inquiry into congressional policy outside of the constructs of the Kimbell Foods analysis.

\section{APPLICATION OF THE KIMBELL FOODS TEST}

United States v. Kimbell Foods, Inc. ${ }^{100}$ establislied a two-part analysis to evaluate the necessity of a federal common law rule of claim priority for federal agencies. The analysis examines two issues: first, whetlier Congress intended federal law to goveru the agency; and second, whetlier federal courts should fashion a uniform priority rule or incorporate state law.

In Kimbell Foods, the Court apphed this analysis to reject the arguinents of the SBA and FHA that the liens held by tliein should be governed by a uniform federal rule of first priority. ${ }^{101}$ The SBA and FHA claimed in Kimbell Foods, as did the FDIC in the instant controversy, that protection of federal interests justified a uniform rule of priority for federal claims against assets. ${ }^{102}$ The Court based its rejection of the SBA's and FHA's argument on the determination tliat the purpose of a uniform rule is to promote speed, which the SBA's and FHA's loan evaluations did not require. ${ }^{103}$ Just as the SBA's and FHA's argument failed in Kimbell Foods, the FDIC's argument in favor of a uniform priority rule over bank sliareholders in the collection of judgments against bank officers and directors should fail because the FDIC does not, and caimot, require speed in restructuring disputes.

As stated above, the first step in the Kimbell analysis requires a determination of whether Congress intended federal law to govern the operations of the federal agency under review. The FDIC easily satisfies this imitial hurdle. A long line of cases supports the argument that federal law apphies to federal agencies cliarged with regulating federal prograins. ${ }^{104}$

100. 440 U.S. 715 (1979).

101. See id. at 740 .

102. See id. at 729.

103. See id. at 732-33.

104. In Kimbell Foods, the Court noted that it has "consistently held that federal law governs questions involving the rights of the United States arising under nationwide federal programs." Id. at 726; see also Clearfield Trust Co. v. United States, 318 U.S. 363, 366-67 (1943) ("The duties iniposed upon the United States and the rights acquired by it . . . find their roots in . . f federal sources. In absence of an applicable Act of Congress it is for the federal courts to fashion the governing rule of law according to their own standards.") (footnote and citation onitted); Gunter v. Hutcheson, 674 F.2d 862, 869 (11tlı Cir.) ("[T]he FDIC operates under authority derived from a specific statutory sclieme passed by Congress in exercise of a 'constitutional function or power' to protect and stabilize the national banking systen. Hence, federal law applies."), cert. denied, 459 U.S. 826 (1982). But see Trigo v. FDIC, 847 F.2d 1499, 1502-03 n.4 (11th Cir. 1988) (holding that 
The problem with applying a federal common law priority rule to FDIC judgment collections hes in the second prong of the Kimbell Foods analysis-whether a federal common law rule of priority is necessary to fill this gap im federal legislation. ${ }^{105}$ Generally, when no federal statute governs the issue of priority of hens or claims held by federal agencies, ${ }^{106}$ federal courts have discretion to fashion a federal common law rule. 107 Kimbell Foods established a three-factor balancing test to determine when federal courts should exercise this discretion. This test primarily focuses on whether a uniform rule is necessary to protect federal interests: ${ }^{108}$

[First,] federal programs that "by their nature are and must be uniform in character throughout the Nation" necessitate formulation of controlling federal rules. ... [Second, a]part from considerations of uniformity, we must also determine whether application of state law would frustrate specific objectives of the federal programs. If so, we must fashion special rules solicitous of those federal interests. [Third,] our choice-of-law inquiry inust consider the extent to which application of a federal rule would disrupt commercial relationships predicated on state law. ${ }^{109}$

As the following analysis will show, the three factors enumerated in Kimbell Foods reveal that courts should not estabhish a uniform priority rule for the FDIC over shareholders im the collection of damages and settleinent awards against bank-related defendants.

federal law governs the corporate function of the FDIC because it operates in exercise of a constitutional function or power, but the FDIC as receiver does not pursue a strong federal policy and so is governed by state law of receiverships).

105. See Kimbell Foods, 440 U.S. at 728.

106. Resort to federal common law is only necessary where Congress has not provided for treatment of the matter under consideration. See Milwaukee v. Illinois, 451 U.S. 304, 313-14 (1981).

107. The Court in Kimbell Foods specifically directed federal courts to supplement statutes:

That the statutes authorizing these federal ... programs do not specify the appropriate rule of decision in no way limits the reach of federal law. It is preeisely when Congress has not spoken " in an area comprising issues substantially related to an established program of government operation," " that ... federal courts [should] fill the interstices of federal legislation "according to their own standards."

440 U.S. at 727 (quoting Uinited States v. Little Lake Misere Land Co., 412 U.S. 580, 593 (1973) and Clearfield Trust Co. v. United States, 318 U.S. 363, 367 (1943)).

108. The Supreme Court held in Kimbell Foods that "[c]ontroversies directly affeeting the operations of federal programs, although governed by federal law, do not inevitably require resort to uniform federal rules." Id. at 727-28. If a uniform rule is not necessary, then the federal rule will incorporate the relevant state law. Id.; see also Wilson v. Omaha Indian Tribe, 442 U.S. 653 (1979) (holding that Indian title is a matter of federal law, but adopting Nebraska law as the appropriate federal rule). For a discussion of the circular practices of generating federal law and tlien adopting state law as the federal rule, see Scott A. Rosenberg, Note, The Theory of Protective Jurisdiction, 57 N.Y.U. L. REV. 933, 964-1002 (1982).

109. Kimbell Foods, 440 U.S. at 728-29 (quoting United States v. Yazell, 382 U.S. 341, 354 (1966)) (footnotes and citations omitted). 


\section{A. Federal Programs That by Their Nature Must Be Uniform in Character}

The first factor of Kimbell Foods's balancing test is whether a uniform rule of federal priority is necessary to achieve Congress's goals for a federal program. Thus, the crucial determination is whether the federal agency, because of the nature of its goals, can operate only if it has a uniform rule that gives priority to federal interests.

Federal courts applying the first factor of the Kimbell Foods test to a possible rule of priority for a federal program have consistently focused their structural analysis on whether the agency's operations require a quick determination of how to proceed. ${ }^{110}$ Thus, speed is the primary justification advanced by the FDIC and rehed upon by the courts for uniformly placing the interests of a federal agency over the interests of private individuals.

The crux of the circuit split between Jenkins and Gaff is a difference over whether the decision on how best to manage a failed institution generates a need for speed in FDIC judgment collection. The Sixth Circuit in Gaff found that speed was necessary in deciding whether to hquidate the institution or to enter a purchase and assumption transaction, and thus found that the FDIC needed a uniform rule of priority. ${ }^{111}$ In so doing, the Sixth Circuit rehed on a line of cases in which federal courts have created federal common law rules to facilitate the FDIC's valuation of bank assets in determining the cost of entering into a purchase and assuniption transaction. ${ }^{112}$ In contrast, the Eleventh Circuit rejected these cases as not analogous to the Jenkins facts because of the practical impossibility of including tentative future judgment income in the failure management decision. ${ }^{113}$

A significant issue in determining whether the FDIC should have a uniform rule of priority is thus whether the precedent dealing with purchase and assumption transactions is analogous to the judgment collection cases. As the following discussion will show, this precedent is not analogous, and speed is not a crucial factor in the FDIC's judgment collections; therefore, the FDIC should not have priority over the interests of depository institution shareholders.

110. See FDIC v. Bank of Boulder, 911 F.2d 1466, 1474-75 (10th Cir. 1990) (granting federal common law priority over borrowers to facilitate FDIC's quick review of bank records), cert. denied, 111 S. Ct. 1103 (1991).

111. See Gaff v. FDIC, 919 F.2d 384, 389 (6th Cir. 1990).

112. See id. at 387-88.

113. See FDIC v. Jenkins, 888 F.2d 1537, 1540 n.4 (11th Cir. 1989). 
1. The Need for Speed in the Purchase and Assumption Cost Test Cases. Before engaging in a purchase and assumption transaction, the FDIC must determine that the deposit insurance fund would suffer a greater loss in a hiquidation than it would in a purchase and assumption transaction. ${ }^{114}$ When the FDIC evaluates the merits of a purchase and assumption transaction, it applies what is known as the cost test. This test provides an estimate ${ }^{115}$ of low much of a bank's assets the purchasing institution will return to the FDIC as receiver and the FDIC receiver will in turn convey, along with its causes of action, to the FDIC as corporate insurer. ${ }^{116}$ The cost of a purchase and assumption transaction is equal to the difference between a bank's liabilities and its collectible assets; this is the amount the FDIC must pay in casli to the purcliasing mstitution in exchange for its assumption of an mstitution's liabilities. The cost test compares that number to the cost of hquidation, whicli is $\$ 100,000$ (or less for depositors witl accounts of less than $\$ 100,000$ ) multiplied by the number of depositors. If the cost of a purchase and assumption transaction is less than the cost of liquidation, the FDIC will quickly prepare for a sale of the bank's assets and liabilities to a solvent institution.

Federal courts liave concluded in several cases that the reatization of the FDIC's goal of promoting stability and confidence in the banking systein througli purchase and assumption transactions requires a uniform federal rule of priority for the FDIC's right to collect on returned assets over borrowers' rights to assert defenses. ${ }^{117}$ The FDIC often niakes the decision to enter a purcliase and assumption transaction overnight so

114. The FDIC has broad discretion to determine which disposition is most cost-effective. See 12 U.S.C. $\$ 1823(\mathrm{c})(4)(\mathrm{A})$ (1988) ("No assistance shall be provided . . . in an amount in excess of that amount which the corporation determines to be reasonably necessary to save the cost of liquidating ... such uninsured bank[s].") (emphasis added).

115. See Gunter v. Hutcheson, 674 F.2d 862, 870 (11th Cir.) ("Because of the time constraints involved, the only method of evaluating potential loss open to the FDIC is relying on the books and records of the failed bank to estimate what assets would be returned by a purchasing bank and to estimate which of those assets ultimately would be collectible."), cert. denied, 459 U.S. 826 (1982).

116. See 12 U.S.C.A. § 1821 (k) (West 1989).

117. For a discussion of how a uniform federal rule of priority against borrowers and other creditors facilitates a purchase and assumption transaction (P\&A), see FDIC v. Bank of Boulder, 911 F.2d 1466 (10th Cir. 1990):

[Without a] uniform rule allowing FDIC/Corporation to acquire nontransferable assets of failed banks in the course of a P \& A transactions[] ... FDIC/Corporation ... [would be] faced with an enormous administrative burden in trying to determine whether or not to finance a P \& A.... To require the FDIC/Corporation to [determine the transferability of every asset] under the stringent time constraints of a $\mathbf{P} \& \mathbf{A}$ is asking the impossible. 
that a bank can reopen under the purchasing bank's name the next business day. Therefore, the FDIC must conduct the cost test with the utmost speed. 118

The general rationale of cases dealing with purchase and assumption transactions is that if the FDIC were not permitted to rely on a bank's records, the FDIC could not conduct an accurate cost test and, therefore, could not use the purchase and assumption method of assisting banks. The Sixth Circuit in FDIC v. Wood"19 articulated this dilemma: "[T]he essence of a purchase and assumption transaction is speed. If the FDIC is forced to examine the bank's files to determine the value of its notes im hight of the defenses to thein, the transaction will not take place."120

The federal common law rule of priority enables the FDIC to rely on a bank's records by preempting various state law defenses that borrowers might assert-such as usury or unlawful transfer of letters of credit-in order to be excused from payment on a loan. Such state law defenses render a financial institution's assets uncertain. Without the federal common law priority, the FDIC would have to hitigate each disputed claim to determine whether it is collectible. Such a system would prevent the FDIC from conducting a cost test, which is based on the accuinulated value of collectible assets, and thus run afoul of Congress's

Hence, the option of handling bank failures through the P \& A method would be foreclosed. Such a result runs directly counter to the policies behind the creation of the FDIC-proinoting stability and confidence in the banking systein.

Id. at 1474-75. But see FDIC v. Galloway, 613 F. Supp. 1392, 1402 (D. Kan. 1985) (holding that a uniform federal holder in due course rule is not necessary to the FDIC's assumption of non-negotiable instruments because these instruments represent a minority of a bank's assets and thus have a minimal effect on the FDIC's cost test), rev'd 856 F.2d 112 (10th Cir. 1988).

The FDIC argues that the prospect of collecting judgments against bank officers and directors is an important factor in performing the cost test. Jenkins addressed this argument, but found that the statement of an FDIC bank hquidation specialist who admitted that the possibility of such judgment had "not been identified as assets and that it would be impossible to evaluate such claims" indicated that this sort of judgment is not a component of the cost test. FDIC v. Jenkins, 888 F.2d 1537, 1540 n.4 (11th Cir. 1989).

118. Speed was a primary concern in Bank of Boulder:

Making the determination of whether a $\mathbf{P} \&$ A would be less expensive than a simple hquidation requires a quick review of the failed bank's books and records. This review of assets inust be quick-usually overnight - because a P \& A transaction requires the bank to reopen quickly in order to maintain the going concern value of the failed bank.

911 F.2d at 1470 (emphasis added).

119. 758 F.2d 156 (6th Cir.), cert. denied, 474 U.S. 944 (1985).

120. Id. at 161; see also Gunter v. Hutcheson, 674 F.2d 862 (11th Cir.), cert. denied, 459 U.S. 826 (1982):

[D]ecisions concerning the appropriate method of dealing with a bank failure must be made with extraordinary speed if the going concern value of the failed institution is to be preserved. Subjecting the FDIC to the additional burden of considering the impact of possibly variable state law on the rights involved could significantly impair the FDIC's ability to choose between the hquidation and purchase-and-assnunption alternatives in handling a bank failure.

Id. at 869 . 
intention that the FDIC conduct a cost test before entering a purchase and assumption transaction. ${ }^{121}$ In response to this problem, the Sixth Circuit created a uniform federal rule of priority for the FDIC in Wood by granting the FDIC holder in due course status, which exempted the FDIC from state usury law defenses to interest debt. ${ }^{122}$ More recently, the Tenth Circuit created a similar rule of FDIC priority in FDIC v. Bank of Boulder ${ }^{123}$ by preeinpting state restrictions on transfers of letters of credit. 124

In Wood, Bank of Boulder, and other cost test cases, the courts concluded that, because of the need for speed and accuracy in the cost test, the FDIC could not conduct purchase and assumption transactions without a uniform rule that granted it priority over borrowers and co-creditors by preempting state law defenses to FDIC claims. The effect of a uniform rule im this context is to allow the FDIC to rely on a bank's written records without regard to various state law provisions concerning secret agreements with outsiders, contributory neghigence, and other personal defenses.

The Sixth Circuit approached $\dot{G} a f f,^{125}$ a case dealing with collection of damages from wrongdoing bank directors, as if it were essentially a cost test case. The court assumed that the FDIC required an estimate of the value of a judgment against the bank directors in order to accurately conduct the cost test. ${ }^{126}$ The court then reasoned by analogy from the cost test cases and concluded that the FDIC should be accorded a priority over shareholders. ${ }^{127}$ The court's error in Gaff was that it equated the valuation of damages against bank directors with the valuation of bank assets. However, whereas the FDIC can and inust conduct asset valuation with speed for purposes of the cost test, a valuation of damages necessarily awaits the conclusion of hitigation or settlennent negotiation. A

121. Under 12 U.S.C. $\$ 1823(\mathrm{e})$ (1988), the FDIC may enter into a purchase and assumption transaction whenever, in the judgment of the Board of Directors, such an action will reduce the risk or avert the threatened loss to the FDIC.

122. See Wood, 758 F.2d at 161.

123. 911 F.2d 1466 (10th Cir. 1990).

124. The court reasoned that a rule of priority for the FDIC enabled the FDIC to achieve the goal of purchase and assumption transactions:

A uniform rule permitting FDIC/Corporation to acquire otherwise nontransferable assets in a P \& A eliminates the need for detailed examination of the failed bank's assets and of varying laws. Cost estimates can be inade quickly and with greater accuracy, and P \& A's can thereby be implemented with fewer risks and with the necessary speed. Because the $P$ $\& A$ is an extremely valuable tool, such a uniform rule furthers the obvious advantages of $P$ $\&$ A's and the interests of the federal deposit insurance program.

Id. at 1475 .

125. Gaff v. FDIC, 919 F.2d 384 (6th Cir. 1990).

126. See id. at 389.

127. See id. 
proper application of Kimbell Foods's first factor to judgment and collection cases focuses on whether a uniform rule of priority for the FDIC over bank shareliolders is necessary for an efficient management of the FDIC's decision on how to handle its receivership.

2. Speed as a Justification for Uniformity. A priority in judgment and settlement collection does not facilitate the FDIC's decisionmaking because, irrespective of priorities, even the FDIC admits that damages are too speculative to contribute to the cost test before a determination of liability has occurred. ${ }^{128}$ Thus, an analogy to the cost test cases cannot answer the first Kimbell Foods factor because speed is the premise for its satisfaction in the cost test cases, and it is precisely this premise that the judgment collection cases lack.

Kimbell Foods itself addressed the issue of speed as a justification for a uniform rule of federal priority. ${ }^{129}$ The SBA and FHA argued that the security interests guaranteemg their loans required a uniform rule of priority over other lienholders because they did not have time during loan application reviews to evaluate state law. ${ }^{130}$ The Court held, however, that the necessity of a pamstakingly lengtliy evaluation of the credit worthiness of loan applicants indicated that there was ample time for the SBA and FHA to research and to satisfy security interest requirements under state law. ${ }^{131}$ Thus, the SBA and FHA did not require a uniform rule to facilitate operation of their federal loan programs; speed was not miperative and did not create a need for uniformity. Similarly, the fact that FDIC's litigation against bank officers and directors typically takes years to complete precludes the FDIC from fixing a value on a judgment against bank officers and directors. Even if the FDIC considers speed in the judgment valuation to be miperative, speed cannot be achieved; therefore, speed does not create a need for uniformity in judgment collection.

The Sixtl Circuit correctly observed in Gaff that the framework of a bank closure must often be built overnight. ${ }^{132}$ The court, however, erroneously iguored the fact that judgments agamst officers and directors have no relevance to the FDIC's decision whetler to liquidate a bank or

128. See FDIC v. Jenkins, 888 F.2d 1537, 1540 n.4 (11th Cir. 1989) (FDIC bank liquidation specialist revealed in deposition that the FDIC lias not identified claims against third parties as assets for purposes of the cost test because the value of sucli claims is "impossible to evaluate").

129. See Kimbell Foods, 440 U.S. at 732-33.

130. See id.

131. See id.

132. See Gaff v. FDIC, 919 F.2d 384, 389 (6tlı Cir. 1990) ("[T] he FDIC must operate under severe time constraints when it closes a bank. Unlike the SBA and [FHA], which have time to structure their transactions, some FDIC bank closure transactions occur overniglit."). 
to sell its collectible assets and liabilities to a solvent institution. There are two reasons why such judgments have no relevance to this decision.

First, the FDIC uses its priority in cost test situations to rely on the face value of a bank's assets. Claims against bank officers and directors do not have face value until they are fully hitigated; thus, the FDIC cannot calculate a definite figure to represent a judgment or settlement in the cost test. A federal common law rule of priority for the FDIC over shareholders could only facilitate the FDIC's decision to liquidate or to enter a purcliase and assumption transaction if the outcome of its hitigation against the officers and directors liad concluded and the FDIC had already been awarded a specific amount of money. In such a situation, an analogy to the purcliase and assumption cases would be appropriate; priority for the FDIC would enable the agency to include a fixed amount in its cost calculation witliout concern that the number would change. ${ }^{133}$ Until the FDIC lias been awarded any damages froin officers or directors, lowever, it cannot reasonably fix a value on those damages to include in the cost test.

Second, a judgment agamst bank officers and directors never affects the valuation of returned assets because the FDIC never ultimately sells its cause of action against bank officers and directors to the purchasing institution. ${ }^{134}$ Whetler or not the FDIC decides to liquidate a failing bank and pay off up to $\$ 100,000$ per account or to enter a purchase and assumption transaction, the FDIC will retain its potential cause of action against officers and directors. Any judgment resulting froin sucli a cause of action is thus irrelevant to the cost test the FDIC undertakes. Thus, although the FDIC must conduct the cost test witlı speed, it is not necessary that the FDIC arrive at any quick valuation of a judgment because the value of the judgment lias no effect on the cost test.

133. It is arguable, however, that a federal common law rule of FDIC priority over shareholders, even limited to situations in which all suits have already concluded, would still not pass the balancing test because the purpose of a federal common law rule in all these cases is to promote predictability in the cost test. After the FDIC has already conducted its hitigation, it would presumably be aware of its priority in collection against hable defendants or their insurance companies and able to form a quick judgment of its effect of its priority ou the cost of a purchase and assumption transaction. Thus, once predictability is achieved, the need for a uniform federal common law rule disappears. See FDIC v. Gulf Life Ins. Co., 737 F.2d 1513 (11th Cir. 1984):

[T] he primary reason for such a [federal common law] rule is to allow the FDIC to reach a considered opimion that a purchase and assumption transaction will better protect the FDIC from loss than a hiquidation. To the extent the FDIC knows of a defense, its ability to form this judgment is uminpaired. Thus, if the FDIC actually knows of any ... enrichment defense at the time it enters the purchase and assumption transaction, it is subject to the defeuse.

Id. at 518. Other cases have held, however, that knowledge is immaterial. See, e.g, FDIC v. Merchants Nat'1 Bank, 725 F.2d 634, 640 (11th Cir.), cert denied, 469 U.S. 829 (1984).

134. See supra text accompanying notes 114-17 for a description of the inechanics of the FDIC's cost test. 
In conclusion, an analogy between an FDIC priority in judgment collection and an FDIC priority in asset collection (for purposes of the decision between the liquidation and purchase and assumption remedies for bank failures) is inappropriate. Whereas the FDIC must be able to value bank assets with great speed to manage efficiently a bank failure, the FDIC does not require, nor is it even possible to require, speed in its assessment of the value of a judgment against bank officers and directors. Thus, the first factor in the Kimbell Foods analysis militates against an FDIC priority. The FDIC does not require a uniform priority rule over depository institution sliareliolders im judgment collection against officers and directors.

\section{B. The Effect of the Application of State Law on the Specific Objectives of a Federal Program}

The second factor in the Kimbell Foods balancing test is whether the application of state law to the operations of the federal prograin would frustrate the prograin's goals. Before conducting any meaningful substantive evaluation of an FDIC priority over depository institution sharelolders in light of this second factor, however, it is important to comprehend the exact inquiry this factor requires.

Kimbell Foods's second factor is analytically similar to the first. In fact, in Gaff, the Sixtl Circuit collapsed the first factor (necessity for uniformity) into the second factor (whether application of state law would frustrate the FDIC's goal of assisting failed or failing banks). ${ }^{135}$ In that case, the court answered the first factor of the balancing test witl a statement that responded to the second factor of the balancing test: "the FDIC has not prepared itself for the application of state law to its transactions."136 Moreover, the Sixth Circuit referred to the uniformity argunnent (the first factor inquiry) in the cases it used as support for its contention that state law would impede the FDIC's goals (the second factor inquiry). For exanple, the Sixth Circuit cited FDIC v. Bank of Boulder's holding that the "FDIC may acquire [a] note not transferable under state law because of need for uniformity" as support for its own holding that an FDIC priority satisfies Kimbell Foods's second factor. ${ }^{137}$.

135. See Gaff, 919 F.2d at 388-89.

136. Id. at 389.

137. Id. (citing FDIC v. Bank of Boulder, 911 F.2d 1466, 1470 (10th Cir. 1990)). 
Kimbell Foods specifically held that the need for uniformity and the impact of state law are separate inquiries. ${ }^{138}$ Thus, although the distinction between Kimbell Foods's first and second factors is subtle, any application of the Kimbell Foods analysis inust comprehend this difference. One workable distimction between the two focuses on the difference between the burdening effect of compliance with up to fifty state laws and the substantive effect of applying a typical state statute to the federal program. This distinction seems to be the one the Tenth Circuit adopted in Bank of Boulder when it found that the state law, which restricted transfer of certain kinds of assets, prevented the FDIC as receiver from transferring certain returned assets to the FDIC as insurer:

If transfer restrictions are enforced against FDIC/Corporation, it may not be able to collect on the nontransferable assets and P \& A's become more expensive. In light of the congressional requirement that $\mathbf{P} \& \mathrm{~A}^{\prime} \mathrm{s}$ be less costly than liquidation, mcreasing the cost of $P \& A$ 's could very well prevent $P$ \& A's in many cases. Elimination of $P \& A$ 's as an option for FDIC/Receiver would cause a great imterference in the effective performance of the FDIC's mission to stabilize the bankiug industry. ${ }^{139}$

Thus, a proper application of the second factor to an FDIC priority over depository institution shareholders in collecting judgment and settlement awards requires a review of the method by which state law determines distribution of assets to judgment creditors.

The laws of the various states goverming distribution of a judgment debtor's assets to judgment creditors have undergone extensive development im this country to the point of great sophistication. ${ }^{140}$ Unless a debtor's assets are sufficient to satisfy all judgment and other obligations, state laws concerning receivership will govern the distribution of the debtor's assets to secured and unsecured creditors. ${ }^{141}$ A judgment creditor who is diligent enough to levy under her judgment before the judgment debtor's estate goes into receivership acquires a lien that a receiver

138. See Kimbell Foods, 440 U.S. at 728 ("Apart from considerations of uniformity, we must also determine whether application of state law would frustrate specific objectives of the federal programs.") (emphasis added).

139. Bank of Boulder, 911 F.2d at 1476 (emphasis added).

140. See 75 C.J.S. Receivers $\S 4$ (1952).

141. 44 C.J.S. Insolvency $\S 6$ (d) (1945) ("The persons qualified to file a petition [for involuntary insolvency under state law] are determined by the statutes, which usually accord the right to 'any creditor." "). 
cannot divest. ${ }^{142}$ Under state "grab laws," the priorities of these competing hens are a function of chronology: The judgment creditor who first can levy under judicial process wins first satisfaction. ${ }^{143}$

Once a receiver has been appointed, however, no creditor can obtain any preference by lien, nor is the receiver subject to attachment, execution, garnishment, or otlier similar process. ${ }^{144}$ If the debtor's estate goes into receivership before a judgment creditor reduces her claim to a lien, then that creditor's interest will take an equal pro-rata dividend with all other unsecured creditors of the debtor's estate. ${ }^{145}$

An FDIC priority of claims does not pass the third factor because these laws are not difficult to apply. The coinpliance burden for the FDIC to determine which party, as between itself and a shareloolder, the state law would allow first to collect a judgment is minimal: The first to levy under its judgment becomes the senior lienholder. Therefore, an application of Kimbell Foods's second factor reveals that an FDIC priority that would preeinpt state law is inappropriate because the FDIC's goals would not be frustrated by deferring to laws easily applied and consistent among the states.

142. The inechanies of turning a judgment into a lien are relatively simple. The creditor must levy execution on the judgment by dehvering to the slieriff a writ of execution (to seize tangible property) or a writ of garnishment (to seize intangible property). 33 C.J.S. Executions $\$ 88$ (1942). The slieriffs seizure of the debtor's property creates a judgment lien in favor of the creditor. Id. $\S 123$. This hen is not destroyed by the subsequent appointment of a receiver of the debtor's estate. Id. $\S 128(\mathrm{a})$.

In soine states, lowever, as in the federal Bankruptcy Code, attachment and execution liens that were levied within a certain period of the insolvency proceedings are dissolved by those proceedings under state insolvency statutes. See, eg. , Belfast Sav. Bank v. Lancey, 45 A. 523 (Me. 1900); Wright v. Dawson, 18 N.E. 1 (Mass. 1888).

In certain cases, when a plaintiff shows proper grounds, she may be able to obtain a writ of attacliment before judgment. Attachment is a provisional, statutory remedy that enables the plaintiff to attach the defendant's property, after service of a coinplaint and summons and before judgment, to secure the payment of a subsequent judgment. 7 C.J.S. Attachment $\S 3$ (a) (1980); id. $\S 23$. If the plaintiff ultimately obtains a judgment in her favor, she must perpetuate the lien by ordering the sheriff to levy under the writ of attachment. Id. $\S 170$.

143. 53 C.J.S. Liens $\$ 14(\mathrm{~b})(1987)$.

144. 75 C.J.S. Receivers $\$ 134$ (1952); see also Union Carbide Corp. v. Kentuckiana Sales Co., 423 S.W,2d 243 (Ky. Ct. App. 1968) (finding that judgment creditor did not obtain a valid lien on property in possession of receiver before execution of judgment).

145. 44 C.J.S. Insolvency $\S 14(\mathrm{e})(2)(\mathrm{b})(1945)$ ("Dividends are based on the claim as proved and allowed, and the stage of the proceedings. . . . In insolvency practice, a dividend is a proportional paynient to the creditors out of the insolvent estate."); see also In re Farmers' Excli. Bank, 37 S.W.2d 936 (Mo. 1931) (general creditors are entitled to all of the assets belonging to the debtor).

It is arguable tlrat a judgment claim that comes within the ainbit of an officer's or director's professional liability insurance policy lias a special right to that policy under the law of constructive trusts. This argument depends on an analogy betwcen an insurance fund for the benefit of judgment claimants and a trust fund for the benefit of certain beneficiaries. Under state receivership laws, trust fund beneficiaries are entitled to collection on the trust fund as against general creditors. See Williains v. S.M. Snitlı Ins. Agency, 84 S.E. 235, 236 (W. Va. 1915). 


\section{Potential Disruption of Commercial Relations Predicated on State Law}

The third factor in the Kimbell Foods balancing test is whether a uniform federal rule would disrupt commercial relations predicated on state law. In applying this factor in Kimbell Foods, the Supreme Court held that adoptimg a uniform rule of first priority for the voluntary federal loan programs of the SBA and FHA would significantly interfere with the settled expectations of other henholders under state law. ${ }^{146}$

Bank shareholders are the parties most affected by an FDIC priority over bank shareholders im hitigation agamst and settlements vith bank officers and directors. Therefore, Kimbell Foods's third factor requires a review of the expectations of bank shareholders with respect to hitigation and damages collection agamst officers and directors, and of how an FDIC priority would affect those expectations.

Whether investors purchase bank stocks with the expectation that they will be able to hold their officers and directors accountable for mismanagement or fraud is in dispute. The court in Gaff held that because successful professional hability claims are so infrequent, bank shareholder claims do not rise to the level of "settled commercial practices," 147 and therefore no settled commercial expectations ${ }^{148}$ would be frustrated by a federal rule giving the FDIC priority. ${ }^{149}$

This argument ignores, however, the observed reality of tremendous mcreases in shareholder hitigation during periods of scandal and crisis ${ }^{150}$

146. See Kimbell Foods, 440 U.S. at 739.

147. Gaff v. FDIC, 919 F.2d 384, 390 (6th Cir. 1990).

148. The Sixth Circuit uses the terms "expectations" and "practices" interchangeably. Whether these terms suggest different standards is unclear, but possible. For example, the Kansas district court in FDIC v. Galloway, 613 F. Supp. 1392 (D. Kan. 1985), rev'd 856 F.2d 112 (10th Cir. 1988), used the expectations standard to determine that a federal common law holder in due course rule would disrupt existing use of non-negotiable instruments, but also held that application of state law to the FDIC's assumption of non-negotiable instruments would not frustrate the FDIC's activities because the frequency of such notes is negligible, i.e., not a settled commercial practice:

The reason there is little dashing of commercial expectations in cases involving negotiable instruments is that one who signs such an instrument can reasonably expect that he will eventually be asked to pay a lolder in due course. Granting the FDIC holder in due course status after a bank's failure thus imposes no greater hability on the maker/drawer of a negotiable instrument than lie had reasonably expected to bear. However, one who signs a non-negotiable instrument reasonably expects to avoid liaving to contend with a holder in due course. ...

$\ldots$

... By clroosuig not to comply with the requirements for negotiability, one who executes a non-negotiable imstrument inakes a conscious decision not to waive any personal defenses he might liave.

Id. at 1402 (empliasis added).

149. See Gaff, 919 F.2d at 390.

150. In a ground-breaking study of sliareliolder litigation trends between 1971 and 1978, Thomas M. Jones found that: 
such as the present. No empirical studies yet exist on the frequency of bank shareholder hitigation during this well-publicized period of crisis in the banking and savings and loan imdustries. The publicity of this crisis, however, has very likely stirred up hitigation by outraged investors in banks in the saine way that the Watergate scandal generated a rash of shareholder hitigation over questionable political contributions. If this prediction is accurate, bank shareholders who are troubled by news of fraud and mismanagement im banks will certainly expect to be able to lold their bank's officers and directors accountable for any misconduct.

Another concern in identifying the expectations of bank shareholders regarding litigation against officers and directors is whether the expectations of shareholders in national banks differ from those of shareholders in state banks. The corporate structure of national banks is determined by the National Bank Act and the Comptroller's regulations; whereas the corporate structure of state banks varies according to state law. This distimction may suggest that sliareholders of national banks expect federal law to govern their relationships with the bank. ${ }^{151}$ The history of congressional efforts to preserve the dual banking system through the "competitive equality" doctrine, lowever, rebuts this contention. This doctrine constrains the permissible activities and services of a national bank to the law of the state in whicll the national bank is located, thus facilitating competitive equality between national and state banks in each state. ${ }^{152}$ The competitive equality doctrine lias been inost restrictive in the area of national bank branching, as governed by the McFadden Act. ${ }^{153}$ A long line of cases interpret the McFadden Act to

\footnotetext{
[A] significant portion of the suits included in [the] study resulted from revelations inade with respect to investigations into corporate political contributions, both domestic and foreign. Of the total 228 suits filed between January 1, 1971 and December 31, 1978, 53 (or 23.2\%) complained only of payoffs, bribery, illegal contributions, or related inatters. In addition, several suits included bribery-related complaints along with other issues.

$\ldots$ [The number of political payoff-related suits rose sharply beginning in 1974 and had the effect of] shift[ing] the slope of the time trend line from negative to positive; without these suits, the trend in the incidence of shareholder suits is actually downward.
}

Thomas M. Jones, An Empirical Examination of the Incidence of Shareholder Derivative and Class Action Lawsuits, 1971-1978, 60 B.U. L. REv. 306, 322 (1980).

151. Although Gaff did not provide any support for such a contention, it used the distimction to distinguish Jenkins: "[T]he failed bank in Jenkins was a state-chartered bank, not a national bank. Thus, the policy reasons for applying federal law inay differ somewhat in this case than in the Jenkins case." Gaff v. FDIC, 919 F.2d 384, 396 (6th Cir. 1990). Note that Howard v. Haddad, 916 F.2d 167 (4th Cir. 1990) (denying FDIC a federal common law rule of claims priority over shareholders), also involved a state bank.

152. See Henry N. Butler \& Jonathan R. Macey, The Myth of Competition in the Dual Banking System, 73 CORNELl L. Rev. 677, 701-05 (1988).

153. McFadden Act, ch. 191, § 7, 44 Stat. 1228, 1228 (codified as anended at 12 U.S.C. § 36(c) (1988)). The McFadden Act promotes equality between national and state banks by permitting national bank branching only to the extent that branches may be established by state banks under state law. First Nat'1 Bank v. Walker Bank \& Trust Co., 385 U.S. 252, 256-61 (1966), provides an 
require the Comptroller of the Currency to apply state law branching restrictions when considering national bank applications for branches. ${ }^{154}$ Thus, investors in national banks can reasonably anticipate the application of state law to the operation of a national bank, including the right to pursue a cause of action against officers and directors for unsafe banking practices.

Kimbell Foods's third factor requires a court to determine that a unifornn federal rule of priority would not disrupt state comınercial practices before according a federal agency such a rule. An FDIC priority would stymie fraud and mismanagement suits by bank shareholders who fear that at some point between their first investment in the hitigation and the ultimate receipt of an award the FDIC might decide to imitiate its own suit. Shareholders with good cases would be likely to experience great intimidation by an FDIC priority over their interests in the collection of a judgment. A federal common law rule of priority encourages FDIC usurpation of all successful officer and director hability suits. The FDIC would simply have to wait until a court awarded dainages to a shareholder and then file suit before the shareholder could collect. The FDIC's action would stay the shareholder's receipt of the award. Such a systematic exploitation of shareholders would lead to a decrease in this kind of shareholder action, which is otherwise beneficial for its deterrent effect on management conduct. Moreover, an FDIC priority over bank shareholders in the collection of judgments against officers and directors could result in a general devaluation of bank stocks to reflect the de facto

excellent legislative history of the McFadden Act and the policy of competitive equality between national and state banks:

The [McFadden Act] originated in the House and, in substance, proposed that both national and state banks be permitted to establish "inside" branches ... in those States that permitted branch banking at the time of the enactment of the bill. The intent of the Congress to leave the question of the desirability of branch banking up to the States is indicated by the fact that the Senate struck from the House bill the time limitation, thus permitting a subsequent change in state law to have a corresponding effeet on the authority of national banks to engage in branching.

Id. at 258.

154. See, e.g., First Nat'l Bank v. Dickinson, 396 U.S. 122 (1969) (holding that because Florida does not confer branching privileges on state banks, the congressional policy of competitive equality forecloses the Comptroller of the Currency from permitting a national bank to set up armored car or stationary receptacle branches in Florida); First Nat'1 Bank v. Camp, 465 F.2d 586 (D.C. Cir. 1972) (holding that the Coinptroller of the Currency must conform to the appropriate state's law on branch banking), cert denied, 409 U.S. 1124 (1973); Springfield State Bank v. National State Bank, 459 F.2d 712, 717 (3rd Cir. 1972) (holding that in considering a national bank's branching application, the Comptroller inust "follow and apply the whole relevant statutory and decisional law of the [appropriate] state as interpreted by its courts and applied to its statc banks"); National Bank v. Wayne Oakland Bank, 249 F.2d 445 (6th Cir. 1957) (holding that a branch of a national bank may not be established even with the Comptroller's approval when that establishment is prohibited by state statute), cert. denied, 358 U.S. 830 (1958). 
deprivation of the right to sue bank officers and directors. ${ }^{155}$ Thus, the third factor in the Kimbell Foods analysis also argues against an FDIC priority over shareholders in judgment collection because of the negative effect an FDIC priority would have on shareholders' expectations regarding the right to protect their equity interest against misconduct by bank officials.

A federal rule of FDIC priority over financial institution shareholders fails each of Kimbell Foods's three factors. First, the FDIC does not by its nature require a uniform rule. Second, apphication of state law does not frustrate specific objectives of the federal deposit insurance system. Third, application of a federal rule of priority would disrupt established commercial relationships.

\section{FIRREA DOES Not IMPLICITLY GRANT THE FDIC PRIORITY OVER BANK SHAREHOLDERS}

The FDIC contends that a congressional intention to provide the FDIC a priority over all other claimants in its suits against bank-related defendants is implicit in FIRREA. ${ }^{156}$ Not only is the FDIC's assertion completely unfounded, but the prospects for enactment of an express priority in the near future are minimal. A careful consideration of the legislative history of FIRREA indicates that Congress has negatively responded to the notion of an FDIC priority, and therefore las not "imphicitly" provided for such a priority in the current matrix of FDIC powers.

155. A possible public policy counter-argument may be made that deprivation of slrareliolders' riglits to sue bank officers and directors, although unfair to the expectations of sliareliolders in the sliort-run, would encourage sliareliolder scrutiny of bank stocks before failure, and thus imduce responsible operation of banks by managers who fear sliareholder disapproval. The conclusion that the deprivation of sliarelolders' rights would lead to more responsible bank operation is questionable, however, because sharelıolder discipline probably does not prevent bank failure. Professor Helen Garten suggests that clianging bank failure policy to encourage more sliareliolders discipline would not decrease bank failures for four reasons: (1) sharelolders who are the last to receive distribution of assets in the event of failure already have an incentive to monitor their banks; (2) managers do not fear slrareholder disapproval because the regulatory scheme discourages bank takeovers despite depressed share values; (3) managers can tolerate depressed sliare prices as long as deposits are available; and (4) portfolio diversification theory suggests that diversified shareliolders nay welcome additional risk-taking by bank management if it promises high returns. Helen $A$. Garten, What Price Bank Failure?, 50 OH1o ST. L.J. 1159-62, 1176-80 (1989). For a discussion of other evidence that the current bank failure policy dulls sliareliolders' and creditors' incentive to reduce the threat of bank failure, see Jonathan R. Macey \& Geoffrey P. Miller, Bank Failures, Risk Monitoring, and the Market for Bank Control, 88 CoLuM. L. Rev. 1153, 1167, 1184 (1988).

156. Pub. L. No. 101-73, 103 Stat. 183 (codified as amended in scattered sections of 12 U.S.C.A.); see also Gaff, 919 F.2d at 394-96 ("The equity of the statute supports our conclusion that the FDIC's claims against the Bank's officers and directors slould receive a priority over Gaff's claim."). 
The FDIC argued in Gaff that Congress implicitly intended the FDIC to have priority over bank shareholders in hitigation against bankrelated defendants as a power incidental to satisfying its express obligation under FIRREA to protect its deposit insurance funds. ${ }^{157}$ An analysis of the legislative history of FIRREA, however, does not support the FDIC's claim of implicit authority. Even the provision's proponents have agreed that, unless Congress explicitly enacts the provision, no FDIC priority exists under the current formulation of federal banking law. Additionally, the legislative history of FIRREA indicates that Congress specifically excluded it from FIRREA.

The assertion that Congress imphitity created an FDIC priority is illogical, given Congress's subsequent efforts to enact an exphicit priority provision that has no retroactive effect. One of the priority provision's inost supportive proponents, the late Senator Heinz, admitted that the provision, as included in recent post-FIRREA legislation, would have no retroactive effect on the rights of shareholders who commenced causes of action before enactment of the provision. ${ }^{158}$ In fact, many versions of the priority provision in recent banking reform bills contain an explicit "no retroactivity" clause. ${ }^{159}$ The natural implication of a non-retroactivity clause is that Congress does not intend to subject an mdividual to a law (in this instance a law that provides FDIC priority over shareholders that did not exist at the time a shareholder filed suit) that did not exist at the time the individual chose to file suit. If Congress had intended to create miphicitly an FDIC priority in FIRREA, it would not have einployed a "no retroactivity" clause.

Moreover, as the Eleventh Circuit in FDIC v. Jenkins pointed out, ${ }^{160}$ Congress specifically rejected an amendment, Section 214(o) of Senate Bill 774, that would have explicitly granted the FDIC a priority over shareholders in the enactment of FIRREA:

In any proceeding related to any claim acquired under section 11 or 13 of this Act against an insured financial institution's director, officer,

\section{The court stated:}

The FDIC reasons that as minimizing the depletion of the insurance fund is an express goal of the FDIC's statutory framework, the FDIC could not carry out its alleged statutory mission unless it had the ability to assert priority over the shareholders who are seeking recovery from the same assets as the corporation and that the need for the priority rule is thus "implicit" in the statutory scheme of the FDIC.

Gaff, 919 F.2d at 394-95.

158. See Banking Committees Approve Budget Packages Containing BIF Premium Bills, 1990 Daily Rep. Execs. (BNA) No. 199, at A-14 (Oct. 15, 1990) ("The provision would not apply retroactively to pending eases, Heinz said.").

159. See S. 3194, 101st Cong., 2d Sess. § 208(b) (1990) ("The amendment ... shall not apply to suits, claims, or causes of action of depositors, creditors, or shareholders commenced before the date of enactment of this Act.").

160. 888 F.2d 1537, 1538 n.1 (11th Cir. 1989). 
... or any other party einployed by or providing services to an insured financial institution, any ... cause of action brought by the [FDIC] shall have priority over any ... cause of action asserted by depositors, creditors, or shareholders of the insured financial institution .... This priority shall apply to both the prosecution of any : . . cause of action, and to the execution of any subsequent judgments resulting froin such suit. ${ }^{161}$

The U.S. Senate Committee on Banking, Housing, and Urban Affairs recommended and included an analysis of Section 214(o) in its coinmittee report dated January 3, 1989.162 Opposition in the House of Representatives caused the joint conference committee unequivocally and exphicitly to reject the provision. ${ }^{163}$ Representatives Staggers and Ghckman, both members of the conference committee, explained in the Congressional Record that the House Judiciary Committee conferees ardently blocked section 214(o) in conference. As Representative Ghickinan stated:

The Judiciary Committee conferees, in particular, believed strongly that these provisions were inappropriate and the conference committee agreed to rejeet the Senate position, thereby deleting this provision.

Of most concern to the conferees was that portion of section 214 of S. 774 that would have added a new subsection (o) to section 11 of the FDIC Act. ...

The Judiciary Committee conferees-on a bipartisan basis and supported by Banking Committee conferees-insisted that all of proposed new subsection (o), including the priority provision, be deleted from the final legislation. The Senate conferees thereafter agreed to recede and the provision is not included in the conference report. ${ }^{164}$

Representative Glickman indicated that the provision had failed because Congress had not conducted a meaningful study or debate on the inatter, the provision would undermine private enforcement against bank fraud, and it would grant the FDIC an unfair advantage over shareholders:

The conferees rejected [the] absolute "priority" provision for a number of reasons. This provision received no careful study by the Congress

161. S. 774, 101st Cong., 1st Sess. § 214(0) (1990).

162. See Senate Comm. on Banking, Housing, and URban AfFairs, Financial InstituTIONS REForm, RECOVERY, AND ENFORCEMENT ACT OF 1989, S. ReP. No. 19, 101st Cong., 1st Sess. (1989).

163. Section 214(o) is conspicuously missing from the conference report version of FIRREA, which was read into the Congressional Record on August 1, 1989. See 135 CoNG. REc. H4714, H4734 (daily ed. Aug. 1, 1989) (conference report on H.R. 1278). Two days later, conferees explained that the provision had been rejected in conference. See infra text accompanying notes 164 67.

164. 135 CoNG. REC. H4985 (daily ed. Aug. 3, 1989) (statement of Rep. Glickman). 
... [A]s the Judiciary conferees pointed out at soine length, giving the FDIC an absolute priority would undermine fraud enforcennent, would be potentially unfair to private plaintiffs who were innocent victims of wrongdoing, and would be at cross purposes with the thrust of the savings and loan legislation.

If the FDIC was granted an absolute priority, private parties would have little chance of recovery and as a result would no longer bring fraud suits against bank officers and others guilty of wrongdoing. As several of the conferees noted, the ... [SEC], in a [sic] ainicus brief filed in a pending case in the eleventh circuit on this inatter, has argued persuasively that granting such a priority would therefore have a serious adverse impact on enforceinent efforts. Private actions, the SEC stated, are a necessary supplennent to the enforcement efforts of the SEC and the Department of Justice, which do not have the resources to enforce tlie law on their own.

The debate in the conference inade clear that there were other policy reasons as well to drop the Senate priority provision. A number of Judiciary Committee conferees stated that the provision was unfair in allowing the FDIC to intervene at any stage in a ease and stay the proceedings, even if a private party had been hitigating a clain for years. Other conferees insisted that there was no evidence that a priority would benefit the American taxpayers in any meaningful way, especially in view of the likelihood of increased fraud. Finally, concern was expressed that enactinent of a priority would be a disincentive to investment in savings institutions, since an investor would have no recourse if his investment was procured through fraud. ${ }^{165}$

Later that day, Representative Harley O. Staggers, Jr. added:

I want to take a inoment to make certain that the record is absolutely clear with respect to certain provisions that were in the Senate version of the savings and loan legislation ....

The House Judiciary conferees were concerned about this provision for a number of pohicy and procedural reasons. ... [T] [Tere had been no careful study of the priority proposal by Congress. The proposal was not in the draft savings and loan legislation sent to Congress by the administration. No hearings were held on the inatter in either the House or the Senate. The provision was not in the House bill, nor in the Senate bill as introduced. Although the language was added by Senator HEINZ at the request of the FDIC during committee consideration, there was virtually no discussion about a priority in committee and no debate on the Senate fioor.

... The Judiciary Committee conferees-on a bipartisan basisstrenuously argued against the provision as inappropriate .... After the House conferees voted overwhelmingly to insist that the priority 
provision not be included in the conference report, the Senate agreed to recede and the provision was deleted. ${ }^{166}$

Six months later, im response to the FDIC's argument in Jenkins, Representative Staggers charged in a letter to the FDIC that it seriously misrepresented congressional intent and that the FDIC's argument amounted to an attempt to rewrite FIRREA's legislative history:

As House conferees last year for the Judiciary and Banking Committees on the Savings \& Loan bill, we are deeply concerned about a recent filing by the FDIC in the Uirites States Court of Appeals for the Eleventh Circuit in the case of FDIC v. Jenkins (No. 88-3798).

As you inay know, the issue in the Jenkins case is whether the FDIC is entitled to an absolute priority over bank shareholders in claims against officers, directors, and other third parties who inay have been responsible for the failure of a financial institution. On Noveinber 27, 1989, a panel of the Eleventh Circuit held, correctly in our view, that the FDIC was not entitled to such an absolute priority, citing the legislative history of the Financial Institutions Reform Recovery, and Enforcement Act of 1989. . . .

....

.. . Last summer the FDIC suggested that legislative language be included in FIRREA to change the law on priority to conform to its legal arguments in the Jenkins case. This language was overwhelmingly and specifically rejected by the conference and, thereafter, by Congress.

.... [The conferees' vote] was clearly a direct and substantive congressional decision that the FDIC should not have an absolute priority in these cases. ${ }^{167}$

The foregomg testimony is the only public mention of the shorthived $\$ 214(0)$, and it does not mdicate a broad congressional mtention to accord the FDIC any priority over individual shareholders. The legislative history leaves no doubt, in fact, that Congress wholeheartedly disfavored enactment of an FDIC priority provision in FIRREA, and therefore that the enacted version of FIRREA contains no miphicit authority for such an FDIC priority.

Notwithstanding this explicit rejection of FDIC priority, the Sixth Circuit in Gaff ignorantly disregarded Congress's clear intent by providing the FDIC such a priority in an indefensibly ill-researched opmion:

It is unclear what happened to this provision as the FIRREA Act worked its way hastily through Congress. ... [T] [ legislative history says nothing about why the Senate did not include this proposal. We behieve the best explanation is that Congress thought it best that the

166. 135 CoNG. REC. H4989 (daily ed. Aug. 3, 1989) (statement of Rep. Staggers).

167. Letter from Rep. Harley O. Staggers, Jr. to L. William Seidman, Chairman, FDIC (Jan. 30, 1990), reprinted in 136 CONG. REC. E547, ES47-48 (daily ed. Mar. 6, 1990). 
law of priorities in bank receiverships should be developed by the federal courts on a case-by-case basis. ${ }^{168}$

Contrary to the Sixth Circuit's supposition, Congress had made completely clear "what happened to this provision": Congress rejected it. Therefore, the legislative history of FIRREA does not support the FDIC's contention that the FIRREA implies an FDIC priority.

\section{RECENT Legislative DeVElopments}

Congress has considered a provision for FDIC priority over shareholders in suing and collecting damages agamst bank-related defendants in several recent legislative initiatives, mcluding the inost recent Senate banking reform bill. ${ }^{169}$ While establishing an FDIC priority over shareholders in prosecuting claims and executing judgments against depository institution officers and directors, the Senate bill proscribes

168. Gaff v. FDIC, 919 F.2d 384, 395-96 (6th Cir. 1990).

169. The version of the priority provision that Congress considered most recently is:

SEC. 230. PRIORITY OF CERTAIN CLAIMS

(a) IN GENERAL.-Section 11 of the Federal Deposit Insurance Act (12 U.S.C. 1821) is amended by adding at the end the following:

"(s) Priority of Certain Claims.-

"(1) IN GENERAL.-Subject to paragraph (2), in any proceeding brought by the Corporation, any claim acquired under this section or section 12 or 13 against an insured depository institution's director, officer, employee, agent, attorney, accountant, appraiser, or any other person employed by or providing services to an insured depository institution shall have priority over any claim against that person by a depositor, creditor, or shareholder of the insured depository institution other than a claim by another Federal agency or the Umited States.

“(2) NOTification.-

"(A) IN GENERAL.-If the Corporation receives written notice that a depositor, creditor, or shareholder of an insured depository institution has asserted a claim in a proceeding described im paragraph (1), a claim of the Corporation shall not have priority under paragraph (1) unless the Corporation-

"(i) not later than 180 days after receiving the notice (or if the Corporation acquires its claim after receipt of the notice, not later than 180 days after acquiring the claim)its claim; and

“(I) files with the court a statement that the Corporation intends to pursue

"(II) diligently pursues that claim; and

"(ii) files suit not later than 1 year after receiving the notice (or, if the Corporatiou acquires its claim after receiving the notice, not later than 1 year after acquiring the claim), unless the court extends that period in accordance with subparagraph (B).

"(B) REQUESTS FOR EXTENSIONS.-

"(i) IN GENERAL.-At the Corporation's request, the court shall extend the period for the Corporation to file suit, unless the court finds that granting the extension would result in prejudice to a person's ability to prove the person's claim that would outweigh any harm to the Government resulting from denial of the extension.

“(ii) CONSIDERATION OF CORPORATION'S DILIGENCE.-In making a finding under clause (i), the court shall consider the Corporation's diligence in investigating its claim.

“(3) EFFECT OF PRIORITY.-

"(A) IN GENERAL.-The Corporation's priority shall apply to-

"(i) the prosecution of any suit, claim, or cause of action; and

"(ii) the execution of any judgment resulting from that clain. 
retroactive application of the FDIC priority and sets up an intricate notification system to minimize the risk to shareholders of preemption late in the litigation process.

Although an FDIC priority over bank shareholders lacks endorsement in the House of Representatives, the Senate adopted the priority provision three times: in its versions of FIRREA in 1989;170 in the Ommibus Budget Reconciliation Act of 1990;171 and in Title XXV of the 1990 omnibus crime bill-the Compreliensive Thrift and Bank Fraud Prosecution and Taxpayer Recovery Act of $1990 .{ }^{172}$

More recently, Senator John Heinz included the provision in the Reduction of Cost of Savings and Loan Crisis Act on January 30, 1991, shortly before his death. ${ }^{173}$ Senator Garn also reintroduced the provision

"(B) Limitation.-Paragraph (1) does not give the Corporation priority as to an asset adjudicated to be unavailable to satisfy any judgment resulting from the Corporation's claim.".

(b) APPLICABILITY-The amendment made by subsection (a) shall not apply to any claim of a depositor, creditor, or shareholder commenced before the date of enactunent of this Act.

S. 543, 102d Cong., 1st Sess. $§ 230$ (1991).

170. S. 774, 101st Cong., Ist Sess. $§ 214(0)$ (1989). Congress took the priority provision out of FIRREA because of strong objection by the House during conference. See supra text accompanying notes 163-67.

171. S. 3209, 101st Cong., 2d Sess. $\$ 2006$ (1990). House objection remained strong the second time the Senate proposed an FDIC priority, in the Omnibus Budget Reconciliation Act of 1990. Congress never enacted the Senate version of the Ommibus Budget Reconciliation Act of 1990. Rather, the House version, H.R. 5835, 101st Cong., 2d Sess. (1990), which did not contain an FDIC priority provision, became the Omnibus Budget Reconciliation Act of 1990. Pub. L. No. 101-508, 104 Stat. 1388 (1990).

172. S. 3194, 101st Cong., 2d Sess. $§ 208$ (1990). In the period before the enactment of the crime bill, the priority provision surfaced in various independent depository institution reform bills designed to enhance FIRREA. See Financial Crimes Prosecution and Recovery Act, S. 2735, H.R. 5050, 101st Cong., 2d Sess. § 305 (1990), 136 CoNG. REC. S8031, H3676 (daily ed. June 14, 1990) (introduced as companion bills by Senator Kassebaum and Representative Wyli); Savings and Loan Fraud Money Recovery Act of 1990, H.R. 5410, 101st Cong., 2d Sess. $\S 7$ (1990), 136 CoNG. REC. H5882, H5883 (daily ed. July 30, 1990) (introduced by Representative Oakar); Federal Deposit Improvements Act of 1990, S. 2827, 101st Cong., 2d Sess. $§ 1004$ (1990), 136 CoNG. REC. S9217, S9217 (daily ed. June 28, 1990) (introduced by Senator Garn); Savings and Loan Prosecution Facihtation Act, H.R. 5150, 101st Cong., 2d Sess. $§ 302$ (1990), 136 CoNG. REC. H4201, H4201 (daily ed. June 26, 1990) (placed by House Minority Leader Robert H. Michel). The Senate included the FDIC priority of claims provision, among other provisions from these banking reform bills, in the large savings and loan amendment to Senator Biden's version of the crime bill in July 1990. See Amendment No. 2116, § 259, 136 CoNG. REC. S9580, S9585 (daily ed. July 11, 1990).

The House version of the crime bill, the Comprehensive Crime Control Act of 1990, H.R. 5269, 10lst Cong., 2d Sess. (1990), did not contain the priority provision. After the House of Representatives passed H.R. 5269, the Senate struck all after the enacting clause and essentially re-passed Senator Biden's bill, S. 1970, which did contain the priority provision. 136 CoNG. REC. S16479 (daily ed. Oct. 22, 1990). At conference, just as in FIRREA, the conferees dropped the priority provision and ultimately created a new bill, S. 3266, 101st Cong., 2d Sess. (1990), 136 CoNG. REC. S17861, H13288 (daily ed. Oct. 27, 1990). This new bill became the Crime Control Act of 1990. Pub. L. No. 101647, 104 Stat. 4789, 4859 (1990).

173. S. 293, 102d Cong., 1st Sess. $\$ 1$ (1991), 137 Cong. Rec. S1293 (daily ed. Jan. 30, 1991). 
in the Federal Deposit Insurance Improvernents Act of 1991 on March 13, 1991.174 And finally, the provision is currently under consideration in the Senate as part of the Coinprehensive Deposit Insurance Reform and Taxpayer Protection Act. 175

As recently as last year, the FDIC itself was skeptical that Congress would ever enact an FDIC priority of claims provision ${ }^{176}$ because of opposition by the House Judiciary Committee. ${ }^{177}$ The increasing cost of unsatisfied claims to the federal deposit insurance system, ${ }^{178}$ however, may weaken the opposition to the provision in upcoming banking reform legislation.

\section{CONCLUSION}

A federal common law rule of FDIC priority of claims would instruct a court to stay all shareholder actions against officers and directors concurrently being pursued by the FDIC. This Note has considered the inerits of expanding federal common law to aid the FDIC during Congress's deadlock on the issue, and concludes that the Supreme Court's guidelines for federal common law development, expressed in Kimbell Foods, cannot support such an expansion. A rule of priority for the FDIC over shareholders fails every element of the Kimbell Foods test: The nature of the FDIC's operations do not require a uniform rule; state laws on the priority of claims do not frustrate the federal deposit insurance system; and a rule of priority would disrupt established commercial relationships. The Note also dernonstrates that, contrary to the Sixth Circuit's decision in Gaff v. FDIC, an FDIC priority over depository institution shareholders is not implied in FIRREA.

The Sixth Circuit's use of federal common law to establish FDIC priority over depository institution shareliolders has diverted attention

174. S. 651, 102d Cong., 1st Sess. § 105 (1991), 137 CoNG. REc. S3191 (daily ed. Mar. 13, 1991).

175. S. 543, 102d Cong., 1st Sess. § 230 (1991).

176. FDIC general counsel Alfred J.T. Byrne was "less [than] optimistic" that Congress would enact the priority provision in the Comprehensive Thrift and Bank Fraud Prosecution and Taxpayer Act of 1990. See FDIC's Byrne Predicts Safe Passage of Key Provisions in Anti-Fraud Bills, 55 Banking Rep. (BNA) No. 12, at 490 (Sept. 24, 1990).

177. According to one report, House Judiciary Committee opposition to the provision was a prominent reason for the House conferees' rejection of the Heinz provision in H.R. 5835. House conferees also cited the damaging effect of the provision on private lawsuits that deter miproper activity. See Conferees Agree to BIF Premium Provisions Under Reconciliation Bill, 55 Banking Rep. (BNA) No. 17, at 689 (Oct. 29, 1990).

178. See Letter from Robert D. Reischauer, Congressional Budget Office, to Hon. Donald W. Riegle, Jr., Chairman of the Honse Banking Comm. (Oct. 14, 1990) (attaching Congressional Budget Office Cost Estimate stating that the priority provision will both reduce litigation costs and increase settlement recoveries, saving an estimated $\$ 10$ million in 1993, $\$ 30$ unillion in 1994, and $\$ 55$ million in 1995). 
froin the real issue that Congress should consider in any future depository institution regulatory reform: the policy implications of such a priority. A banking policy analysis of whether Congress should provide an FDIC priority is beyond the scope of this Note. Nevertheless, in order to promote an informed debate of the issue, the Note has examined the Senate's recent attempts to enact a provision for such a priority. The goal of this Note is not to discredit congressional expansion of FDIC protections. Rather, the conclusions of the foregoing analysis inerely argue for expansion in the appropriate form-legislation.

The evolution of the cost test line of cases discussed in Part III, according the FDIC various priorities over borrowers, depicts the danger of a cancer-like growth of FDIC priorities founded on federal common law policies of protecting the banking system. The FDIC's special rights and immunities under this precedent now preclude virtually any dispute between failed financial institutions' borrowers and the FDIC. As more financial institutions fail, pressure for new FDIC priorities is likely to develop even more rapidly than in the past. Federal courts slould not encourage this trend by creating a federal common law rule of FDIC priority over shareholders. Such an unwarranted disruption of established commercial practices in the area of shareholder litigation defies the Suprente Court's policy regarding the expansion of federal common law, as set forth in Kimbell Foods. By rejecting a federal common law rule of FDIC priority of claims over shareholders, courts would be sending the issue back to Congress, where it belongs. 